Reprinted with permission from: The Canadian Entomologist. 1996. 128:1021-1055.

Published by: Entomological Society of Canada.

www.biology.ualberta.calesc.hp/homepage.htm

\title{
Effectiveness of gall inducers in weed biological control ${ }^{1}$
}

\author{
P. HARRIS and J. D. SHORTHOUSE \\ Research Centre, Agriculture and Agri-Food Canada, PO Box 3000, Lethbridge, Alberta, Canada T1J 4B1; Depart- \\ ment of Biology, Laurentian University, Sudbury, Ontario, Canada P3E 2C6
}

\begin{abstract}
:
Gall inducers are favoured as biocontrol agents of weeds because they tend to have a narrow host range. Six insect and one nematode gall inducer used in Canada are described in terms of their biology, gall morphology, gall physiology, and effectiveness in weed control. The species differ in plant organ attacked, requirement for moisture, whether the galls are induced by secretions or by severing xylem, and effectiveness, which in part relates to the ability of the gall to import nutrients. The most powerful galls divert assimilates from other sinks via a gall's vascular system joined to that of their host. One of our examples also has mechanisms to compensate for reduction of turgor during drought. Two of the gall inducers enhance their nutrient supply by severing xylem in a plant nutrient sink. One, in the short-term sink of a thistle capitulum, obtains about a quarter of its assimilates at the expense of other capitula. The other, in the long-term sink of a rosette root, approximately halves seed production. Hypotheses are presented to explain various aspects of gall development and function.
\end{abstract}

\section{Introduction}

Classical biocontrol of weeds involves establishing herbivores, usually insects, in new regions to reduce the density of an introduced weed. The technique was used over 125 years ago (Johnston and Tryon 1914) and to date nearly 400 species of insects, several pathogens, nematodes, and vertebrates have been released on over 100 weed species around the world (Julien 1992). On uncultivated land, biocontrol usually achieves the same weed reduction as a herbicide, but it is persistent and does so in a more environmentally friendly and cost-effective manner; cost:benefit ratios can exceed 1:50 (Marsden

\footnotetext{
${ }^{1}$ Lethbridge Research Centre contribution No. 3879499. (Date received: 22 November 1994; date accepted: 16 January 1996)
}

Page 1 of 40 
et al. 1980). To be successful, biocontrol agents must reduce the weed over much of its range by reducing survival, growth, or reproduction, all of which depend on the agent's fecundity, ecological range, susceptibility to parasitism, and the harm it does to the host.

Gall inducers are organisms that induce atypical plant growth. Most are host and organ specific, and live within a chamber in the gall where they feed on special tissues (Abrahamson and Weis 1987). Occasionally, the food of the gall inducer is unmodified tissue within the chamber, but usually it is proliferating parenchymatous cells or "nutritive cells" on the walls of the gall chamber (Meyer and Maresquelle 1983; Bronner 1992). These tissues are a metabolic sink for nutrients from adjacent plant tissues or other parts of the plant. It is this ability to bring nutrients to the organism that distinguishes gall inducers from non-galling organisms in terms of their effectiveness as weed biocontrol agents.

Only $2 \%$ of plant-feeding insects are gall inducers (Dreger-Jauffret and Shorthouse 1992), but 17 out of the 64 weed biocontrol agents released in Canada up to 1993 are gall inducers. This is because they tend to have a narrow host range and hence threaten few non-target plants. Some gall inducers have been highly successful in controlling the target weed, but others have either not established or had little impact. Failures are expensive, because the cost of demonstrating that on release an organism will not damage desirable plants in the new region is about two scientist-years (Harris 1979), currently about $\$ 700,000$.

Our paper summarizes and reviews the literature on seven gall inducers used for weed biocontrol in Canada. It provides a compendium for those interested in the organisms and is arranged with sections under each on biology, development and structure of the gall, gall physiology, and biocontrol value. Our aim is also to improve the selection of effective agents by identifying characteristics of successful and unsuccessful species. Success may be related to mortality from parasitism or to environmental factors, but we believe that a major part of an agent's ability to damage its host relates to the power of the gall as a nutrient sink. We have, therefore, classified galls into four nutritional categories, departing from Dreger-Jauffret and Shorthouse (1992), who used location and appearance, and from Mister (1911), who used cellular organization. Doing the review suggested new ideas on gall development and function, which in several instances we have investigated with preliminary experiments. Where details of these experiments interfere with the flow of the text, we have placed them in an appendix.

The inducer's nutritional categories and the representative species examined are as follows: (1) nutrient supply to the gall not increased, e.g. the sow-thistle capitulum gall of Tephritis dilacerata Loew (Diptera: Tephritidae); (2) nutrients imported from adjacent tissue, e.g. the knapweed ovule gall of Urophora quadrifasciata (Meig.) (Diptera: Tephritidae); (3) nutrients supplied by callus following severance of vascular tissue, e.g. the thistle receptacle gall of Rhinocyllus conicus (Froel.) (Coleoptera: Curculionidae) and the diffuse knapweed rosette root gall of Sphenoptera jugoslavica Obenb. (Coleoptera: Buprestidae); (4) nutrients supplied via a gall vascular system, e.g. the knapweed receptacle gall of $U$. affinis (Frfld.) (Diptera: Tephritidae), the Canada thistle stem gall of $U$. cardui (L.) (Diptera: Tephritidae), and Russian knapweed stem-bud or leaf gall of Subanguina picridis (Kirj.) (Nematoda: Tylenchidae).

Page 2 of 40 


\section{Nutrient supply to the gall not increased}

Tephritis dilacerata Loew (Diptera: Tephritidae). Tephritis dilacerata is a tephritid fly that transforms the capitula of Sonchus arvensis L. (perennial sow-thistle) into a button-like gall. The fly is native to central and northern Europe (Hendel 1927); it has been released, but has not become established in Canada.

Sonchus arvensis is a herbaceous perennial of European origin that is found in all Canadian provinces. It spreads by seeds and easily broken horizontal roots. Flowering occurs from June to September and many wind-borne seeds are produced. The plant is a particular problem in broad-leaved herbicide-sensitive crops such as canola. Peschken et al. (1983) estimated that sow-thistle causes annual losses in canola of $\$ 6.7$ million on the Canadian prairies.

Biology. The biology and host specificity of $T$. dilacerata were studied by Berube $(1978 a, 1978 b)$. The fly lays an average of seven eggs into a capitulum of $S$. arvensis with an average diameter of $3.1 \mathrm{~mm}$. The capitulum size, which reflects its developmental stage, is critical as younger buds abort and older ones cannot be galled. Consequently, the perennial sow-thistle strain of T. dilacerata cannot develop in annual Sonchus spp. which have smaller capitula and faster development. Females oviposit between the bracts without piercing them, which would release latex. The eggs hatch in 4-5 days when the capitulum is elongating rapidly (Berube 1978b), about 12 days before flowering. The three larval instars are completed in 9-10 days.

The gall is formed by contraction of the bracts at the apex to form a button shape (Fig. 1) following consumption of all the ovaries and most of the receptacle, which requires at least five larvae (Shorthouse 1980). The larvae are then contained in the expanded capitulum base, which just before anthesis is $10.2 \mathrm{~mm}$ in diameter compared with $7.7 \mathrm{~mm}$ for uninfested capitula (Berube 1978a). There is intense competition between larvae and those in small capitula produce few, small puparia. In some cases, apparently as a result of crowding, larvae tunnel into the peduncle which becomes swollen (Shorthouse 1980). Pupation occurs in the gall, approximately 15 days after oviposition. Capitula with $T$. dilacerata remain green and turgid for about 7 days after abscission of unattacked capitula, and then dehydrate within hours after fly emergence. The fly is in reproductive diapause from emergence in midsummer until flowering starts the following year. Parasitism of T. dilacerata is negligible in Europe (Schroeder 1974) and absent in Canada.

Development and structure of the $\boldsymbol{T}$. dilacerata gall. The outer involucral receptacle cells (the area at the base of the bracts but above the peduncle) extend after 6 days of larval feeding and reach maximum size about 18 days after egg hatch (Shorthouse 1980). Growth is accentuated by vacuolation and increase of intercellular space (Fig. 2). Vascular bundles extend from the peduncle to the bracts, as in normal capitula (Philipson 1942), and divide the involucral receptacle from the rest of the receptacle. Larvae rarely sever or feed beyond these strands. Nutritive cells are not produced and the only cell proliferation is a small amount of callus associated with larval feeding in the peduncle and on the receptacle at pupation.

Page 3 of 40 
Gall physiology. The stomatal openings in the bracts are $0.3 \pm 0.08$ (SE) $\mu \mathrm{m}$ in both galled and ungalled capitula, but galling suppresses corolla development. Corolla tissue typically has a high water loss so its absence likely helps maintain capituluin turgor. The receptacle's vascular tissue is severed by the larvae of $T$. dilacerata, but this does not lead to callus proliferation, possibly because larval consumption is too fast. The tissue eaten by the larvae is not modified and their food requirements are often so great that they starve, suggesting that it would be advantageous for the fly to distribute its eggs more evenly among capitula; but egg distribution is apparently limited by the need to have at least five larvae to modify the involucre. The lack of normal involucral senescence indicates that the presence of larvae and pupae stimulate the production of cytokinin.

Biocontrol value. The larvae of $T$. dilacerata reduce seed production in sow-thistle, but only in the attacked capitula. Hence, the effect is similar to that of non-galling insects that web bracts together. In Europe, T. dilacerata occurs in over $20 \%$ of $S$. arvensis stands, but galls only $2.5-6.0 \%$ of the capitula (Schroeder 1974).
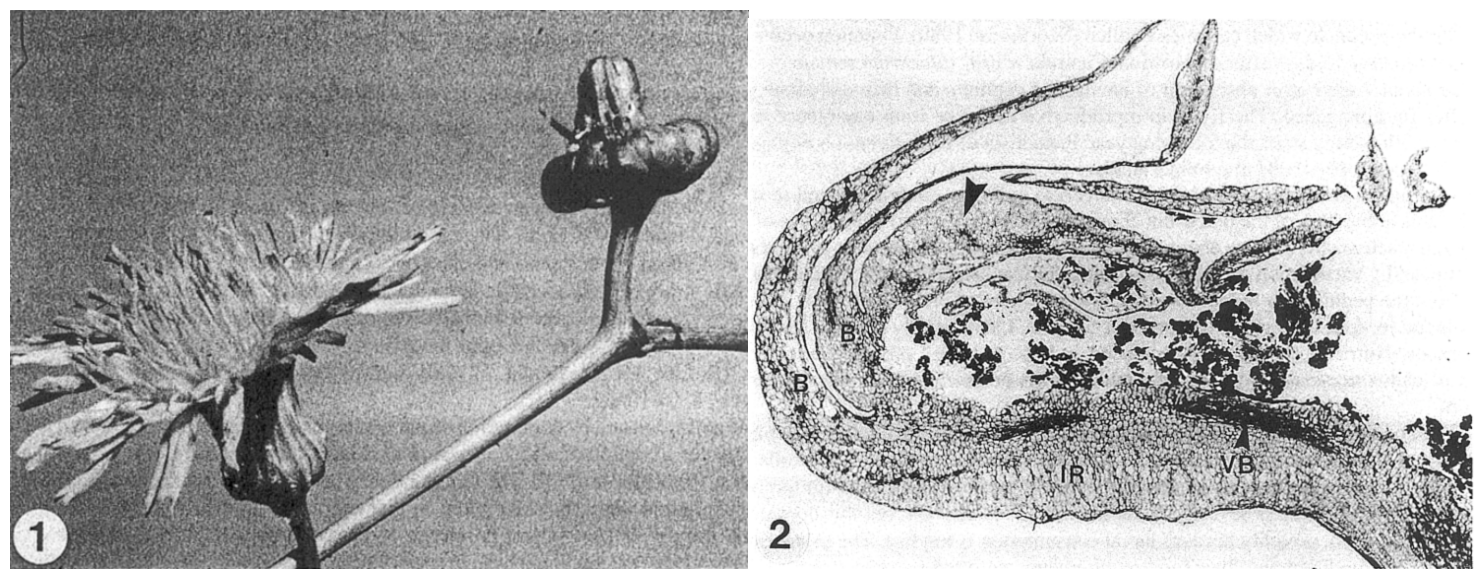

Figs. 1-2. Capitula of Sonchus arvensis modified by Tephritis dilacerata: 1, normal and galled capitulum (without florets), $\times 2 ; 2$, mature gall with laterally expanded involucral bracts (arrows), Safranin-fast green, $\times 12$. Abbreviations: B, bract; IR, involucral receptacle; VB, vascular bundle.

A total of 19,336 flies was released across Canada between 1979 and 1980 without recovery (Peschken 1984), although T. dilacerata has survived in field cages provided with deep litter near Edmonton, AB (A. McClay, pers. com. 1993). From a biocontrol perspective, $T$. dilacerata is a poor candidate because its galls are not nutrient sinks and even if the insect could be established in Canada, seed reduction would probably be small. 


\section{Nutrients imported from adjacent tissue}

Urophora quadrifasclata (Meig.) (Diptera: Tephritidae). Urophora quadrifasciata, which breeds on Serratula and several subgenera of Centaurea, is one of the most common tephritid flies in Europe and Turkey (White and Korneyev 1989). The fly was introduced from the Ukraine to Canada in 1972 where its hosts are C. diffusa Lam., C. maculosa Lam., and C. debeauxii Gren and Godron. It is established in British Columbia, Alberta, Quebec, and possibly Ontario.

Centaurea diffusa and C. maculosa are herbaceous Asteraceae of Palaearctic origin, probably introduced from the Caspian Sea region with Turkestan alfalfa seed. These knapweeds thrive on the dry grasslands of southwest Canada, reducing forage production by up to $90 \%$, to the detriment of both ranching and wildlife. In addition, C. diffusa has spiny capitula, which makes it undesirable in recreational areas. The two knapweeds, which infested almost 30,000 ha in British Columbia in 1972 (Watson and Renney 1974), spread to about 83,000 ha by 1984 (Jenson 1984) and threaten 8.4-10.7 million ha in western Canada (Harris and Cranston 1979). The perennial, C. maculosa, flowers mainly in early summer, each plant producing an average of 16 capitula with 26 seeds each, In contrast, $C$. diffusa is largely monocarpic, and on dry range, plants produce an average of 74 capitula with 12 seeds each in succession from mid-summer until frost (Watson and Renney 1974).

Biology. Emergence of U. quadrifasciata in British Columbia peaks in the 3rd week of July, the preferred capitula of $C$. diffusa for oviposition are 5.5-9.5 mm long (Berube 1980) and contain distinct seed embryos. The larvae develop only in pollinated capitula or those attacked by $U$. affinis, indicating a need for a pre-existing nutrient sink. The eggs are laid singly among the developing stamens (Varley 1937), but a capitulum may be attacked several times. Eggs hatch in 3-4 days and each larva bores down a floret to the ovary. The gall arises from the ovary (Fig. 3) and, except for the stretched wall around the larva, is completely consumed at maturity. Larvae complete feeding at the end of the third instar about 20 days after oviposition, when they turn so that their heads are toward the outside. In the first generation, pupation occurs at 20-25 days, about the time achene development is complete, and the adults emerge in 5-6 weeks. The larvae of the second generation, and sometimes the first in C. maculosa, overwinter in the capitulum, which seems to be an adaptation to the short flowering period on summer-dry sites.

Parasitism in Canada by Hyssopus nr. novus Girault and Prototalia carlinarum (Szelenyi and Erodös) (Hymenoptera: Eulophidae) is less than 10\%. With less parasitism and greater knapweed density, U. quadrifasciata is about 15 times denser in Canada than in Europe. The most important mortality in North America is the approximately $70 \%$ predation in sites of $C$. maculosa by the seed-feeding moth Metzenaria paucipunctella Zell. (Lepidoptera: Gelechiidae) (Story et al. 1991), which was introduced as a biocontrol agent of C. maculosa.

Development and structure of the gall. Gall development begins about 8 days after hatching, when the larva has chewed down the floral tube to the ovary (Shorthouse 1989). Here, it consumes the ovule and cells of the inner layer of the ovary wall. The larva then penetrates the base of the ovary and feeds on the adjacent receptacle tissue. The recepta-

Page 5 of 40 
cle cells next to the feeding site proliferate and differentiate into a small zone of nutritive tissue which is supplied by a little new vascular tissue. While the larva feeds on the nutritive tissue, cells of the inner ovary wall proliferate (Fig. 4) and those near the base become cytoplasmically dense. The larva consumes the entire wall except for the paperythin outer layer and, when there are several in a capitulum, may penetrate into the receptacle (Shorthouse 1989).
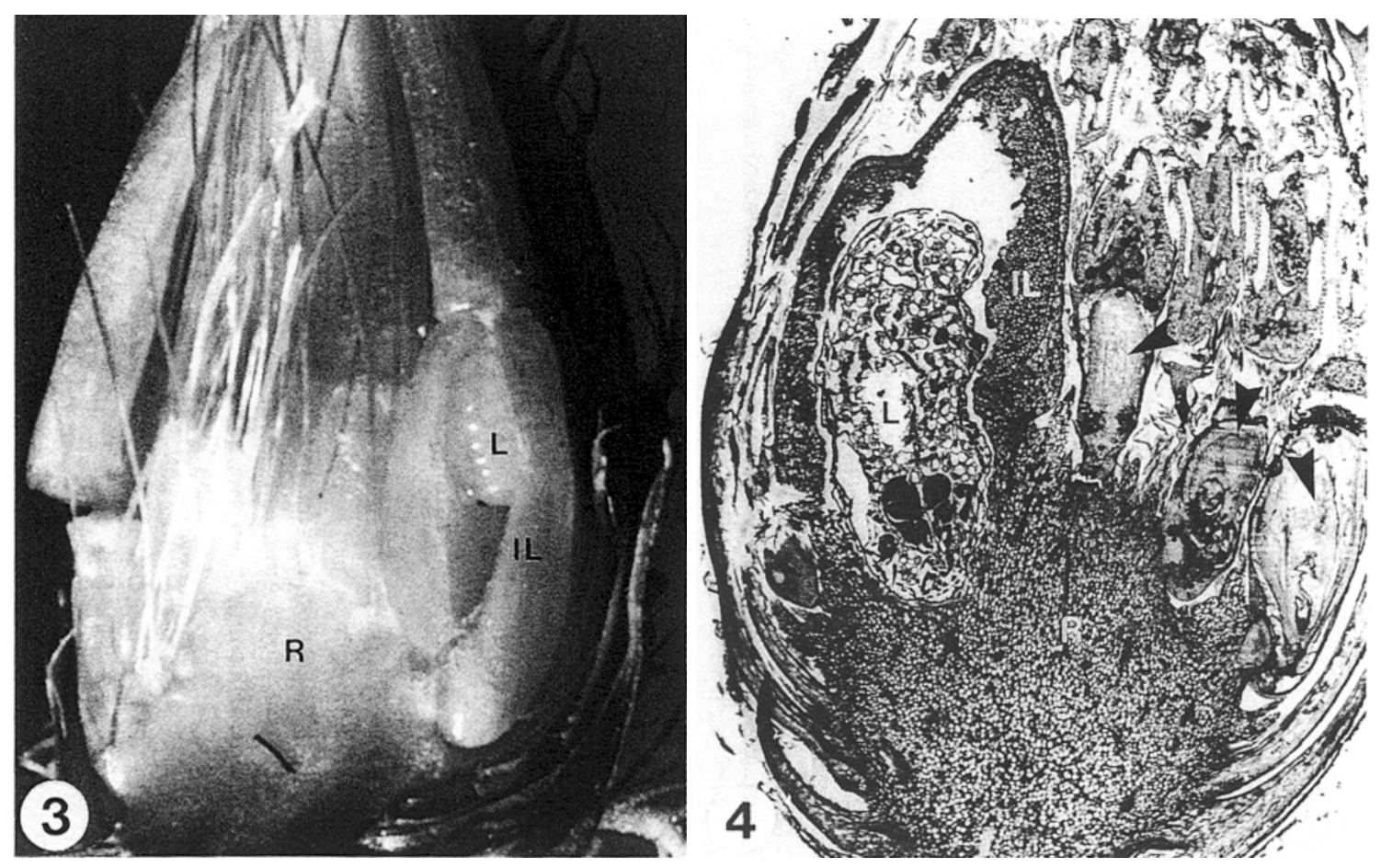

Figs. 3-4. Galls of Urophora quadrifasciata in Centaurea diffussa capitula: 3, capitulum with larva in an ovary, $\times 15 ; 4$, gall with cell proliferation on inner ovary wall and aborted ovaries (arrows), Safranin-fast green, $\times 16$. Abbreviations: IL, inner layer of ovary wall; L, larva; $\mathbf{R}$, receptacle.

Gall physiology. Some of the larval nutrition for $U$. quadrifasciata is obtained from unmodified cells of the ovary wall. However, larval feeding on the receptacle tissue at the base of the gall induces the formation of nutritive tissue and increases the nutrient supply to the galled ovary. Adjacent florets abort and abortion is increased by larval penetration into the receptacle. However, presence of galls does not increase the calorific value of a capitulum (Harris 1980a), so the larvae must be nourished from the normal supply to the capitulum. Final-instar larvae of $U$. quadrifasciata contain on average $17.8 \pm 0.6(\mathrm{SE}) \mathrm{kJ}$, which is less than a single diffuse knapweed seed of $27.2 \pm 0.4$ (SE) kJ. Further evidence that the gall is weak as a metabolic sink is that, in contrast to $U$. affinis, fly development was similar in capitula from a small stand growing on soil with sublethal amounts of the herbicide picloram as from outside it (Table 1). 
Table 1. Number of insects in 50 capitula of Centaurea maculosa from adjacent picloramtreated and untreated soil at Westwold, BC.

\begin{tabular}{lcc}
\hline & \multicolumn{2}{c}{ No. of galls } \\
\cline { 2 - 3 } Treatment & Urophora affinis & U. quadrifasciata \\
\hline With picloram* & 33 (9 larvae dead) & 61 \\
Without picloram & 104 (17 larvae dead) & 54 \\
\hline
\end{tabular}

$* 7.8 \pm 5.2 \mathrm{ppb}$ picloram in the soil at $0-10 \mathrm{~cm} ; 5.4 \pm 4.7 \mathrm{ppb}$ picloram in the soil at $10-20 \mathrm{~cm}$.

Biocontrol value. Florets inhabited by larvae of $U$. quadrifasciata are destroyed and adjacent ones abort; however, there is no decrease in the number of capitula developed (Harris 1980a). Regression analysis indicated that each larva of $U$. quadrifasciata reduced production by 1.9 seeds in C. diffusa (Harris 1980b), so the caloric ratio of fly:displaced seed is 1:2.9.

Urophora quadrifasciata has spread rapidly (Story et al. 1987) and attacks isolated plants as well as stands. Roitberg (1988) showed that the greater dispersal of U. quadrifasciata than $U$. affinis was not related to their performance on a flight mill, so presumably the tendency of $U$. affinis to aggregate on dense stands of its host is behavioural. Average density in 74 samples of 100-200 capitula taken in September-October between 1978 and 1985 in British Columbia was $0.78 \pm 0.08$ (SE) larvae per capitulum on $C$. maculosa and $0.44 \pm 0.08$ (SE) on $C$. diffusa. This compares with $0.057 \pm 0.13$ (SE) larvae per capitulum for C. maculosa in Europe (H. Zwölfer, pers. com.).

Myers and Harris (1980) found that the presence of $U$. affinis in a capitulum tends to discourage attack by $U$. quadrifasciata. Nevertheless, the combination of both species enhances seed reduction. Indeed, the partial displacement by $U$. affinis may increase searching by $U$. quadrifasciata as indicated by our finding that in 1973-1975, a site in British Columbia had $73 \%$ of the capitula attacked by U. quadrifasciata, $54 \%$ by $U$. affinis, and $30.2 \%$ by both.

The biocontrol value of $U$. quadrifasciata is that it destroys some of the seed that escapes $U$. affinis. The fly also adds stability to the level of control between years because the relative success of the two flies changes annually with differences in synchronism of fly emergence and capitulum maturity by as little as a week (Berube 1980). The relative importance of $U$. quadrifasciata should increase as knapweed density declines, because it is less dependent on dense populations of knapweed. However, an equally abundant nongall inducing insect with the ability to forage in the capitulum, of which there are several, would probably be more effective.

\section{Nutrients supplied by callus formed after severance of vascular tissue}

Rhinocyllus conicus (Froel.) (Coleoptera: Curculionidae). Rhinocyllus conicus is a European weevil that develops in thistle capitula of Carduus, Cirsium, Silybum, and Onopordum (Zwölfer and Harris 1984). The weevil qualifies as a gall inducer rather than 
a borer because it induces callus tissue on which the larva feeds preferentially. Rhinocyllus conicus was released in Canada in 1968 and subsequently in the United States, New Zealand, and other countries where it has controlled Carduus nutans. In Canada it is also established on C. acanthoides L. and Cirsium spp.

Carduus nutans and C. acanthoides are biennials or winter annuals dependent on seed production that, prior to the introduction of the weevil, formed persistent, almost pure stands up to $2 \mathrm{~m}$ tall in many places in North America. Carduus nutans produces capitula up to $7 \mathrm{~cm}$ in diameter in an early summer flush that coincides with the $R$. conicus oviposition period, but $C$. acanthoides starts flowering about 2 weeks later to produce a succession of capitula, up to $1.7 \mathrm{~cm}$ diameter, until frost. Only the early capitula of $C$. acanthoides are available to the weevil.

Biology. Rhinocyllus conicus emerges in the spring to feed on the host leaves and oviposits on the involucral bracts, mostly near the peduncle. In Europe, the number of eggs is closely correlated with capitulum size (Zwölfer and Preiss 1983), and although the dense North American populations of this weevil overload capitula with eggs, the number of weevils maturing is related to capitulum size (Zwölfer and Harris 1984). Each egg is covered with masticated thistle tissue which is used by the larva as an abutment for penetrating the capitulum (Zwölfer and Harris 1984). The larvae hatch in 6-9 days, tunnel down a bract and into the receptacle, and feed in the receptacle and peduncle (Shorthouse and Lalonde 1984). At the end of the fourth instar (Fig. 5), the larvae form pupal chambers of frass and faeces. The pupal stage lasts 8-14 days and the teneral adult remains in its chamber for several weeks before leaving to hibernate in the soil litter. About $10 \%$ of the attacked capitula in both Ontario and Saskatchewan have larvae in the peduncle. This has not been observed in Europe and appears to relate to the high density of $R$. conicus. In the peduncle, the larvae tunnel the pith without damaging the vascular bundles and no callus is formed.

In Europe, interspecific competition with other capitulum-infesting insects and parasitism are major causes of mortality (Zwölfer and Harris 1984). In Canada, larval parasitism, by Bracon mellitor Say (Hymenoptera: Bracondiae), is less than 1\%. This parasite attacks a number of weevils and moths including Homeosoma electellum (Hulst) (Lepidoptera: Pyralidae) (Muesebeck et al. 1951), which is common in capitula of C. nutans. Parasitism was similar in the United States, but was $19 \%$ for larvae in the peduncle (Littlefield 1991). Parasitism was 5.3-15.7\% in the capitula of C. acanthoides, compared with 1.8-2.5\% in the larger capitula of C. nutans (Dowd and Kok 1982).

Development and structure of the gall. At the time of larval entry, the upper receptacle has small, closely packed, cytoplasmically dense cells that divide frequently whereas the lower receptacle has randomly arranged, occasionally dividing vacuolate pith-like parenchyma (Shorthouse and Lalonde 1984). Most larvae either tunnel into the upper receptacle, immediately below the ovules, or the region between the upper and lower receptacle. Both regions have extensive vascular systems, which the larvae sever as they feed. The severing produces a rapid proliferation of callus that surrounds the larva in 2-3 days (Fig. 6), but no new vascular tissue is formed. The larvae then feed on the callus and cease tunnelling. In the preferred upper receptacle region, the larvae sever more vascular tissue, callus is formed more rapidly, and there is less tunnelling than in the lower region. The fourth-instar larvae consume more callus than they induce and ultimately 
consume it all. Depending on the size of the capitulum and the number of larvae, the receptacle may be reduced to involucral bracts, pappus hairs, and black pupal chambers composed of frass and faeces.

Gall physiology. All the requirements for callus production are present if the vascular tissue is severed in a plant nutrient sink (see Discussion). The greater production of callus in the upper than the lower receptacle and its absence in the peduncle presumably reflect nutrient distribution in these tissues. Weevils from $C$. nutans are smothered by callus if they attack $S$. marianum, which is exploited by $R$. oblongatus Cap. (Klein and Seitz 1994). In Saskatchewan, the number of larvae per capitulum and the attack of secondary capitula are lower when spring is dry (Zwölfer and Harris 1984), so moisture may be a limiting factor.

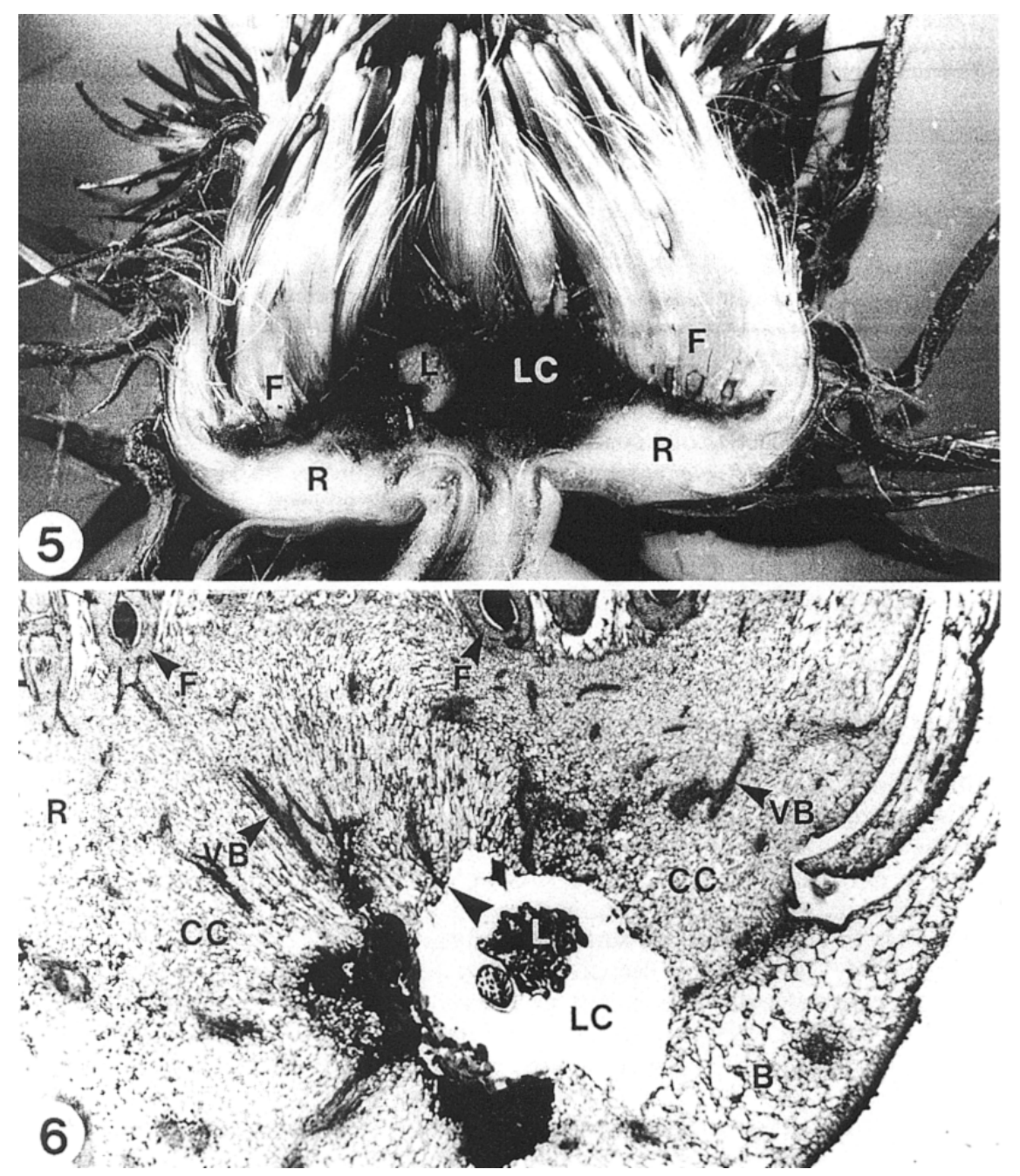

Figs. 5-6. Capitula of Carduus nutans modified by Rhinocyllus conicus: 5, mature capitulum with larvae, receptacle tissues have been consumed, severing the florets, $\times 3$; 6 , receptacle of $\boldsymbol{C}$. nutans with larvae of $\boldsymbol{R}$. conicus surrounded by proliferating callus, Safranin-fast green, $\times 28$. Abbreviations: $B$, bract: $C$, callus cells: F, floret; L, larva; LC, larval chamber; $R$, receptacle, VB, vascular bundles. 
Impact of the weevil on seed production was measured on 2,135 capitula harvested in 1982 shortly before dehiscence from 60 plants of $C$. nutans growing on cultivated land at Regina, SK. Carduus nutans growing in competition with grass normally dies in early August, after the production of secondary capitula, but those in the test continued producing capitula, which had few $R$. conicus, until the plants were killed by frost in midOctober. The receptacular radius was measured and seed and weevil larvae in each capitulum were counted. Seed production varied between similarly sized capitula, possibly reflecting pollination success, but this did not obscure the impact of the weevil (Table 2). Multiple regression analysis showed that seed production increased with receptacular radius and each weevil reduced seed production by approximately 16 seeds in the attacked capitulum, and by one seed for each weevil in each of the five previously formed capitula. These findings suggest that at least $20 \%$ of the larval nourishment is obtained from assimilates diverted to the attacked capitula. This ability to import extra nutrients explains the small effect of larval crowding on weevil size, and the similar size of weevils developing in staminate and in pistillate capitula of $C$. arvense (Harris and Peschken, unpublished).

Table 2. The effect on seed production by Carduus nutans of capitulum diameter, of the number of Rhinocyllus conicus in the capitulum, and of the number in the previous five capitula formed. Determined from a multiple regression of 2135 capitula collected in 1982 shortly before dehiscence from a stand of 60 plants at Regina, SK.

\begin{tabular}{llll}
\hline & $\begin{array}{l}\text { Seed } \\
\text { production }\end{array}$ & $\begin{array}{l}\text { Standard } \\
\text { error }\end{array}$ & Prob $>|\mathrm{T}|$ \\
\hline Radius & +33.1 & 1.2 & 0.0001 \\
Per R. conicus in capitula & -15.9 & 1.0 & 0.0001 \\
Per R. conicus in 5 previously formed capitula & -1.0 & 0.2 & 0.0001 \\
\hline
\end{tabular}

Biocontrol value. According to Crawley (1989), the control of $C$. nutans with $R$. conicus is the fourth most successful weed biocontrol project in the world. The establishment of $R$. conicus in Canada reduced $C$. nutans's seed production by about $50 \%$ and the thistle is now confined mostly to recently disturbed roadsides and to breaks in pasture (Zwölfer and Harris 1984). In Virginia, Kok and Surles (1975) reported that R. conicus reduced $C$. nutans's density by $95 \%$. The weevil has been less effective against $C$. acanthoides because, with the longer flower period, only early capitula are attacked. Consequently, seed reduction is about 10\%. Rowe and Kok (1984) suggested that natural selection will increase the intensity of weevil attack of $C$. acanthoides, but population mixing may prevent this in regions with both thistles.

In conclusion, $R$. conicus is a successful biocontrol agent of $C$. nutans largely because it attacks a high proportion of the capitula. The weevil increases assimilate partitioning to the attacked capitula and consequently reduces seed production in the unattacked ones, but this impact is relatively small. 
Sphenoptera jugoslavica Obenb. (Coleoptera: Buprestidae). Sphenoptera jugoslavica is a beetle endemic to the steppes of east Romania, Bulgaria, northern Greece, and northeastern Turkey, where it forms callus galls in the roots of $C$. diffusa and closely related knapweeds (Zwölfer 1976). Beetles from northern Greece were released in British Columbia in 1976 and are now established throughout the dry belts of the province and the northwest United States. The host plant is described under U. quadrifasciata.

Biology. Adults of S. jugoslavica emerge in early July with the appearance of the first knapweed flowers (Powell and Myers 1988) and for about 2 weeks they can be sweepnetted on warm dry evenings. They feed on knapweed leaves, but usually eat only 0.25 $\mathrm{cm}^{2}$ before departing (Powell and Myers 1988). Feeding is necessary for egg development and oviposition occurs from late July to mid-September. Eggs are wedged between tightly appressed petioles of rosettes with horizontal leaves (dormant plants). Rain during the 14-day incubation period causes eggs and newly hatched larvae to be dislodged by separation of the petioles or crushed by their expansion (Zwölfer 1976). In British Columbia, eggs are also placed in leaf axils of bolting stems up to $4 \mathrm{~cm}$ above the ground and the larvae bore down the stem into the root. Occasionally, well-developed larvae are found developing externally between the petioles of robust rosettes. The beetle is dependent on high temperatures: oviposition on $95 \%$ of knapweed rosettes took 8 days at $30^{\circ} \mathrm{C}$ and 24 days at $25^{\circ} \mathrm{C}$ (Powell and Myers 1988). Most plants receive several eggs, but usually only one larva survives and in rare cases where there are two larvae, the lower is stunted. Usually C. maculosa is not a host, but it is lightly attacked on alluvial sands at Castlegar, BC, where rosette growth is arrested by drought in July-August.

Freshly hatched larvae enter the petiole base and then bore toward the root. The second instar reaches the stem-root transition zone where some remain and others tunnel the root without causing noticeable swelling. However, most larvae penetrate the upper root to create a swelling (commonly about twice the root diameter) in which the larva feeds and overwinters (Fig. 7). Feeding resumes in the spring and pupation, which lasts 10-12 days, occurs in the root. The adult bores out in 2-3 weeks on a warm dry day in JulyAugust.

In the fall, small rosette roots are consumed and so the plant and consequently the larva die. Best survival occurs in large roots, but in robust plants the larva is often found dead embedded in a mass of callus. Powell and Myers (1988) reported that in late August at White Lake, BC, all well-developed rosettes had eggs or larvae, but only $60 \%$ of the plants flowering the following year had been attacked. This can be explained by the eggs not having been laid on seedlings, some of which reached flowering size.

No parasitism or predation has been noted in British Columbia, but in Europe attack rate is low and parasitism high. Zwölfer (1976) dissected 100-500 rosettes from each of 30 sites on the Romanian Black Sea coast, but found the beetle at only three, which had $3-5 \%$ of the rosettes attacked. Over half the larvae were parasitized and there was predation by elaterid larvae and Pterlonche inspersa Staud. (Lepidoptera: Gelechidae) for a total mortality of around $70 \%$. 


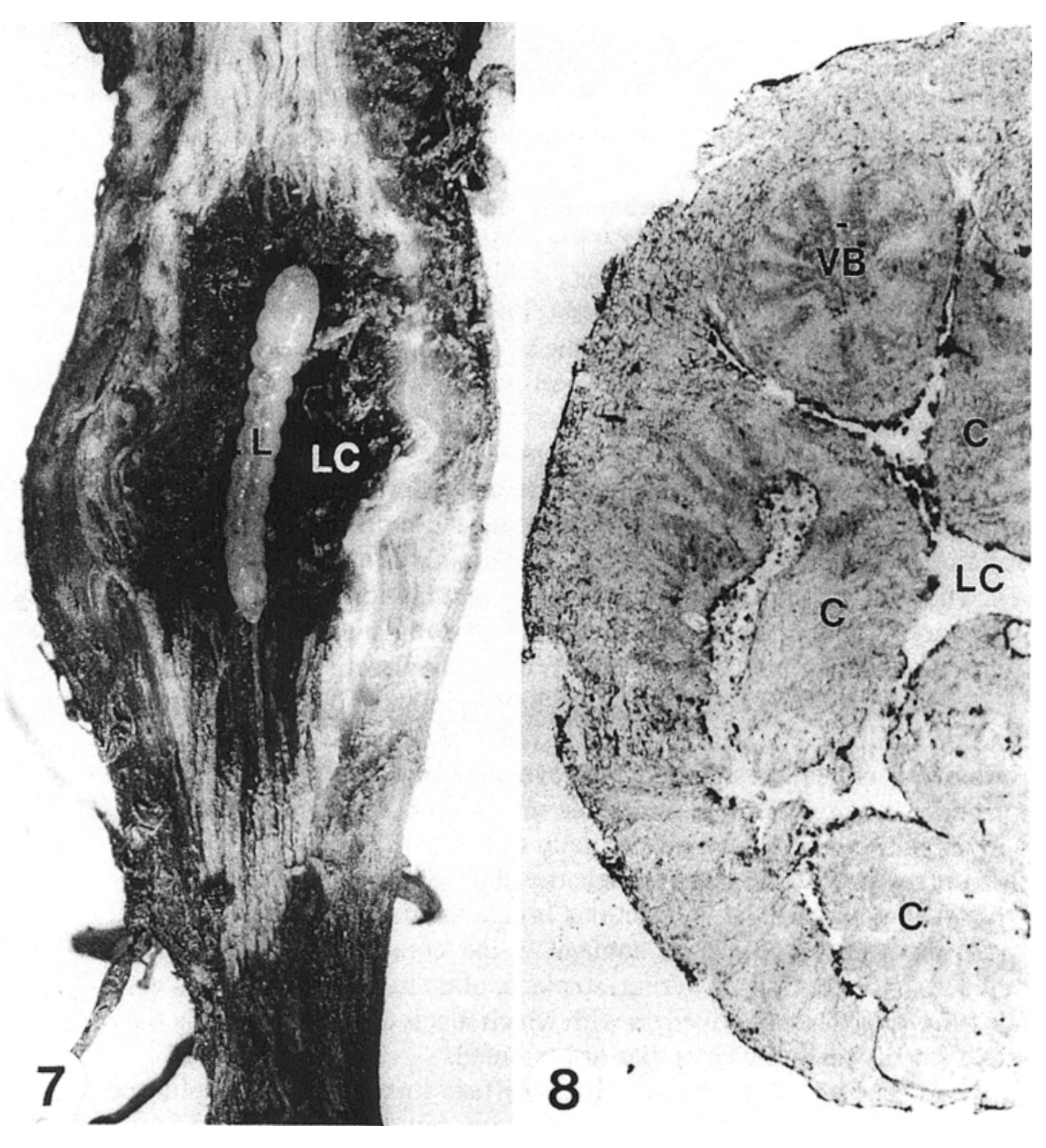

Figs. 7-8. Upper root of Centaurea diffusa modified by Sphenoptera jugoslavica: 7, gall, with larva, which enlarges the root, $\times 5 ; 8$, gall with callus protrusions, some of which contain vascular bundles, Safranin-fast green, $\times 20$. Abbreviations: C, callus; L, larva; LC, larval chamber; VB, vascular bundles.

Development and structure of the gall. On consuming the pith in the stem-root transition zone, most second-instar larvae tunnel into the root and feed on parenchyma between the vascular rays. The pith cells lining the tunnel above the larva proliferate to produce clumps of densely packed callus. Supernumary cambia in this callus cause the root to swell. The main larval food is callus and its consumption creates the larval chamber. The larva commonly severs the secondary xylem, leaving pieces in the frass. The chamber surface becomes convoluted with irregularly expanding protuberances of callus (Fig. 8). The larva also feeds on the thick layers of light-brown callus at the chamber base.

Gall physiology. The gall is similar to that of $R$. conicus in that most of the feeding is on proliferating callus formed after the severance of vascular tissue. The knapweed root develops new vascular tissue to bridge the severed portions, which restores the root-shoot connection, but none is developed to supply the gall. 
Biocontrol value. The larva tunnels the plant and severs vascular tissues in the upper root. However, new vascular connections bridge the damage and the tunnelling is of little structural importance. The main damage is the consumption of the assimilates being accumulated in the root for flowering, so plants often remain as rosettes that are attacked in the following year. The effectiveness with which this is done is apparently the reason that in a multiple attack, the lower larva dies or is stunted.

Measurement of the beetle impact on diffuse knapweed is complicated by the two seed-head flies $U$. affinis and $U$. quadrifasciata; but as these attack after the beetle has emerged, they have no direct effect on it. Powell and Myers (1988) found that, in 1983, $S$. jugoslavica-attacked plants produced $41 \%$ less seed than unattacked ones, and, in 1984, the reduction was 57\%. Thus, one larva accounts for about half the assimilates destined for seed production. This is not its full effect because attack delays flowering in some rosettes; $2-5 \%$ of attacked rosettes die in the fall and $12-16 \%$ in the summer. In dry summers, feeding by adults increases seedling mortality.

The combined impact of the beetle and the two seed-head flies has reduced seed production at White Lake from around 35,000 per square metre in 1976 to 475 per square metre in 1989 (Harris 1991). This is reflected in a decline in knapweed cover from 52\% in 1986 to $13.7 \%$ in 1992 (A. Sturko, pers. com.). Thus, the beetle has supplemented the impact of two seed-head flies to divert enough assimilates to reduce seed production to below the threshold needed to maintain the weed population. The need of the beetle for summer-dry sites is not a serious limitation because this is the habitat of its host.

\section{Nutrients supplied via a gall vascular system}

Urophora cardui (L.) (Diptera: Tephritidae). Urophora cardui is a European tephritid fly that induces a large spherical or irregular multichambered gall in the stems of Cirsium arvense (L.) Scop. The fly requires moist sites and is spreading along rivers in Germany at a rate of 100-800 $\mathrm{m}$ a year, but populations are genetically impoverished by only local dispersal by flight, high parasitism, and colonization of new areas by few individuals (Seitz and Komma 1984). The only hosts are C. arvense and C. creticum (Lam.) D'Urv. (an aquatic thistle) (White and Korneyev 1989). In Canada, U. cardui is established in six provinces, but on the prairies it is restricted to the edges of ponds and streams (Peschken 1990).

Cirsium arvense is a herbaceous perennial that reproduces by seed, vegetatively by horizontal roots, and, after cultivation, by root fragments, so it commonly grows in dense patches. The ability of the thistle to thrive in a variety of edaphic, climatic, and plant communities makes it a serious weed, which Peschken and Johnson (1979) estimated to cause losses of \$23 million annually to wheat producers on the Canadian prairies.

Biology. Forsyth (1984) noted that in Quebec, U. cardui oviposited from mid- to late June, when the thistle had completed almost $80 \%$ of its growth in height. Eggs are laid into an apical leaf bud and hatch in about 10 days as second instars (the first-instar exuvium being left in the egg shell). The larvae tunnel down the stem until they reach the zone of vascular differentiation where they induce the gall. The tunnel, which expands as the gall grows, fills with callus (Lalonde and Shorthouse 1984). The newly hatched lar-

Page 13 of 40 
vae produce a secretion that presumably breaks polysaccharide chains as they sink in a pool if placed on agar gel. This secretion presumably plays a role in gall induction. The gall grows for about 30 days to enclose each larva in its own chamber where it feeds little until the gall is mature (Fig. 9). Larvae feed for 30-65 days, then overwinter in the gall, remaining dormant as long as the gall is intact, but pupating when exposed to air. In nature this occurs in the spring with the disintegration of the callus plug in the exit tunnel (Lalonde and Shorthouse 1982). Females mate within a day or two of emergence.

The size and number of larvae in the mature gall varies, but the clutch size is $14.0 \pm$ 2.0 (SE) $n=47$, regardless of stem diameter (Harris, unpublished data). Final gall size is a function of the number of larvae in it (Zwölfer et al. 1970; Lalonde and Shorthouse 1985). Forsyth (1984) noted that the dry weight of galls on main stems $4-7 \mathrm{~cm}$ tall was $3.3 \pm 1.5$ (SE) g compared with $1.0 \pm 0.8(\mathrm{SE}) \mathrm{g}$ for stems $7-13 \mathrm{~cm}$ tall and in the field, the length $x$ width of galls on the main stems was $11.5 \pm 5.0(\mathrm{SE}) \mathrm{cm}^{2}$ compared with 4.5 \pm 2.4 (SE) $\mathrm{cm}^{2}$ for those on laterals, which do not appear until main stem growth is complete. Thus, larval survival is best on young main shoots.

Galls of $U$. cardui in Europe are mainly parasitized by the following Hymenoptera: Eurytoma serratulae (F.) and E. robusta Mayr. (Euryatomidae), Torymus sp. (Torymidae), and to a minor extent by other species such as Habrocytus elevatus Walker (Pteromalidae). Total parasitism in established populations is over 60\% (Zwölfer et al. 1970), but mortality from parasitism is higher as many larvae are killed without parasite development (Zwölfer 1979). In a sample of over 2000 larvae from 100 galls in Nova Scotia, 7.7\% were killed by H. elevatus (Sampson and Ingraham 1990) which may have entered Canada in ships ballast with its main host, the black knapweed gall fly, Urophora jaceana L. (Graham 1969). Paradoxically, with parasitism, 43\% of the larvae failed to emerge, whereas in other regions of Canada without parasites, mortality was $30-90 \%$ (Peschken, pers. com.). Thus, without parasitism, larval survival is similar to that in Europe with high parasitism. Parasitism reduces energy consumption in the unilocular gall of Eurosta solidaginis (Fitch) (Diptera: Tephritidae) by 4.3-8.7 kJ (Stinner and Abrahamson 1979). The effect is probably similar in $U$. cardui, which means that it should improve the nutrition of unattacked larvae and hence their winter survival.

Development and structure of the gall. The gall induced by $U$. cardui, which is described by Lalonde and Shorthouse (1985), is soft and fleshy while growing, but hard when mature. The gall is initiated by the larva severing vascular bundles and feeding on the interfascicular parenchyma, differentiating procambium and pith to form a chamber (Lalonde and Shorthouse 1985). A distinct zone of small, cytoplasmically dense cells forms around each larva (Fig. 10).

Gall growth is marked by the development of procambial strands that eventually become branched xylem, attached to the main vascular system, around the larval chambers. 'Primary nutritive cells' containing starch and lipids accumulate at the ends of the larval chamber. Some are eaten, but the larva grows little (Lalonde and Shorthouse 1985).

At gall maturation, division of the procambium produces 'secondary nutritive tissue' (Lalonde and Shorthouse 1984) with cells that have a large vacuole and accumulate lipids and proteins, but lack starch. Their formation coincides with rapid larval feeding on the remaining primary nutritive cells which leaves the larva surrounded by secondary nutri- 
tive tissue (Fig. 11). Coincidentally, gall parenchyma beyond the nutritive layer becomes lignified. The gall vascular system increases and differentiates with the phloem on the inside of the xylem instead of in its normal external position. During the 36 days of gall growth, mean larval dry weight increases from 0.03 to $0.1 \mathrm{mg}$, but to $7.7 \mathrm{mg}$ during the following 30 days. The larvae consume all secondary nutritive tissue by the end of the maturation stage, leaving each chamber lined with lignified cells.
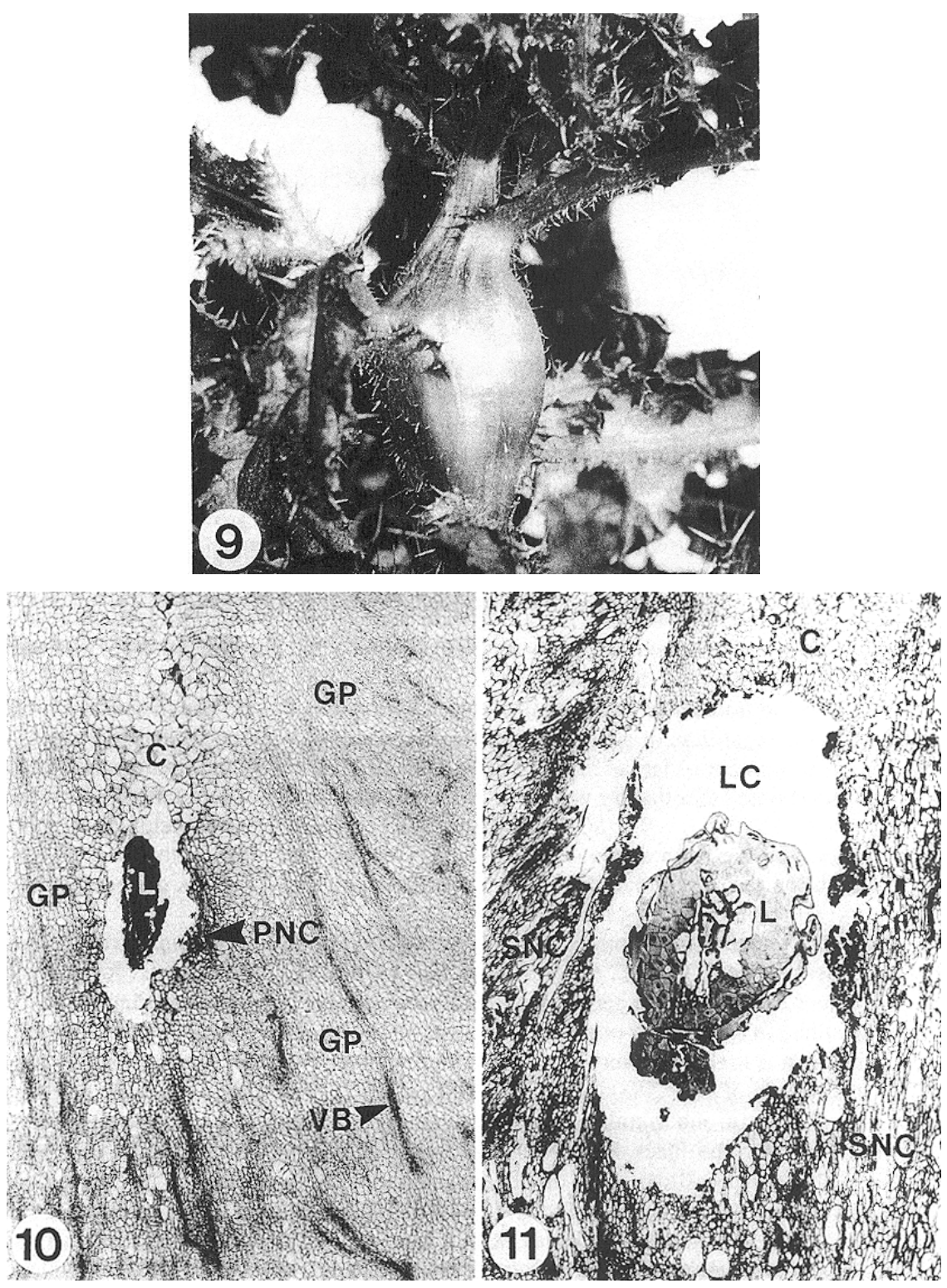

Figs. 9-11. Stem gall of Urophora cardui on Cirsium arvense: 9, mature gall, $\times 1.0 ; 10$, immature gall with larva surrounded by parenchyma with primary nutritive cells near the larva and callus above the larval chamber which forms the escape route for the adult, Schiffs reagent-fast green, $\times 25 ; 11$, mature larva within its chamber surrounded by secondary nutritive cells, Safranin-fast green, $\times 15$. Abbreviations: C, callus; GP, gall parenchyma; L, larva; LC, larval chamber; PNC, primary nutritive cells; SNC, secondary nutritive cells; VB, vascular bundle. 
Gall dehiscence occurs when the callus tissues above the larval chambers degrade. This increases the air exchange in the larval chamber and induces pupation (Peschken and Harris 1975).

Gall physiology. The immature gall of $U$. cardui is a powerful metabolic sink. Alexander (1987) found it accumulated 22 times more picloram than the stem which resulted in cell wall thickening and production of small flies. Forsyth (1984) found that radioactive fructose was accumulated during the growth but not the maturation phase. Similarly, Thibodeau (1985) found that, during the growth phase, 12\% of labelled assimilate from leaves accumulated in the galls at the expense of nutrients to vegetative and flowering apices. In contrast, less than $2 \%$ of the assimilates accumulated in the gall during rapid larval growth. Thus, the main assimilate loss to the plant occurs before the larvae do most of their feeding. The number of larvae in a gall affects its size and assimilate partitioning to the gall. One gall with a single larva accumulated $8.9 \%$ of labelled assimilates, whereas $25.4 \%$ accumulated in a gall with six larvae (Thibodeau 1985). Alexander (1987) found that during early growth, galls had 2.6-3.9 times more indoleacetic acid (IAA) than stem tissue, which, together with a high sugar concentration around the larva would account for the reversal of phloem and xylem positions in the gall (see Discussion). Sugar export from the gall has not been examined, but may occur, as phloem loading is stimulated by high IAA levels (Moorby 1977).

There is less potassium in the gall than the stem and the addition of $10 \mathrm{~kg} / 100 \mathrm{~m}^{2}$ in a strip through a thistle-infested field in New Brunswick had no significant effect on either numbers of galls per stem, larvae per gall, or larval size (Table 3). Similarly, Abrahamson and McCrea (1986) found that the gall inducer E. solidaginis did not benefit from the addition of potassium.

Stems of $C$. arvense have few stomata compared with the leaves $[12.90 \pm 0.73$ (SE) per $\mathrm{mm}^{2}$ vs. $57.09 \pm 5.21$ (SE) per $\mathrm{mm}^{2}$ ] and there was no significant difference between the number of stomata on a gall and an equal length of ungalled stem. However, the aperture (both length and width) of the stomata on the gall increased with the size of the gall (Fig. 12) (Experiment 1, Appendix 1) and the stomata apparently do not close. The result was that gall transpiration loss was $47 \%$ greater than from an equivalent length of ungalled stem (Experiment 2, Appendix 1).

Table 3. The effect on Urophora cardui of fertilizing its host plant, Cirsium arvense, with potassium chloride.

\begin{tabular}{lccc}
\hline & Treated \pm SE & Untreated \pm SE & $p>|\mathrm{T}|$ \\
\hline No. of galls per stem & $2.12 \pm 0.25$ & $1.44 \pm 0.19$ & 0.04 \\
Dry gall weight $(\mathrm{g})$ & $0.66 \pm 0.06$ & $1.01 \pm 0.12$ & 0.005 \\
No. of larvae per gall & $3.98 \pm 0.39$ & $4.68 \pm 0.58$ & 0.3 \\
Live larval weight $(\mathrm{mg})$ & $14.22 \pm 0.43$ & $15.16 \pm 0.43$ & 0.1 \\
\% potassium in galls & $1.51 \pm 0.05$ & $1.13 \pm 0.04$ & \\
\% potassium in stem & $2.11 \pm-$ & $2.04 \pm-$ & \\
\hline
\end{tabular}

Page 16 of 40 
Blocking the gall stomata on plants with eight or more leaves enhanced the power of the gall as a metabolic sink, which is indicated by the larvae from these galls being significantly heavier than those from galls with open stomata. This suggests that the untreated galls on plants with many leaves suffer from the competing leaf transpiration (Fig. 13) (Experiment 3, Appendix 1). The finding of Lichter et al. (1990) that the galls of $E$. solidaginis on Solidago altissima L. were $10 \%$ smaller and had larvae that were $26 \%$ larger than those on $S$. gigantea Ait. may also be related to stomatal expansion and water loss from the gall. Patrick (1984) suggested there is an upper turgor limit regulated by an "off-switch", implying that if turgor was not limiting in the untreated galls of U. cardui on plants with few leaves, their growth would be similar to those with blocked stomata. Gall turgor is less likely to be limiting in the aquatic thistle $C$. creticum than in $C$. arvense, which grows on drier sites.

Gall turgor can also be increased by defoliation of plants with many leaves, as in Experiment 4 (Appendix 1). In this case both the number and total weight of larvae maturing per gall were significantly greater in the defoliated than in the undefoliated stems; however, the weights of the gall shells were not significantly different (Table 4). Larval nutrition depends on the development of nitrogen-rich nutritive cells (during gall maturation) which occurs after the stomata have reached maximum size. The shell of the gall is formed during gall growth and is lignified during the maturation stage. The mature gall of $U$. cardui has a shell with $9.0 \%$ acid-insoluble lignin and $4.1 \%$ acid-soluble lignin (Experiment 5, Appendix 1), so, although lignin has an important role (see Discussion), it comprises a relatively small part of the shell.

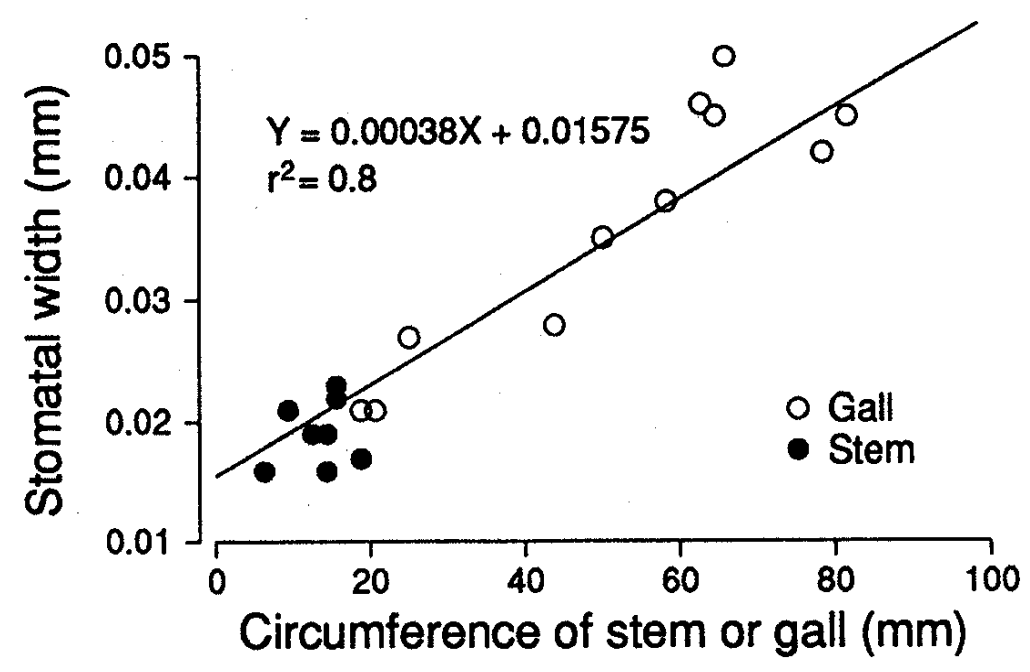

Fig. 12. Relation of Cirsium arvense stomatal width to stem and gall circumference. 


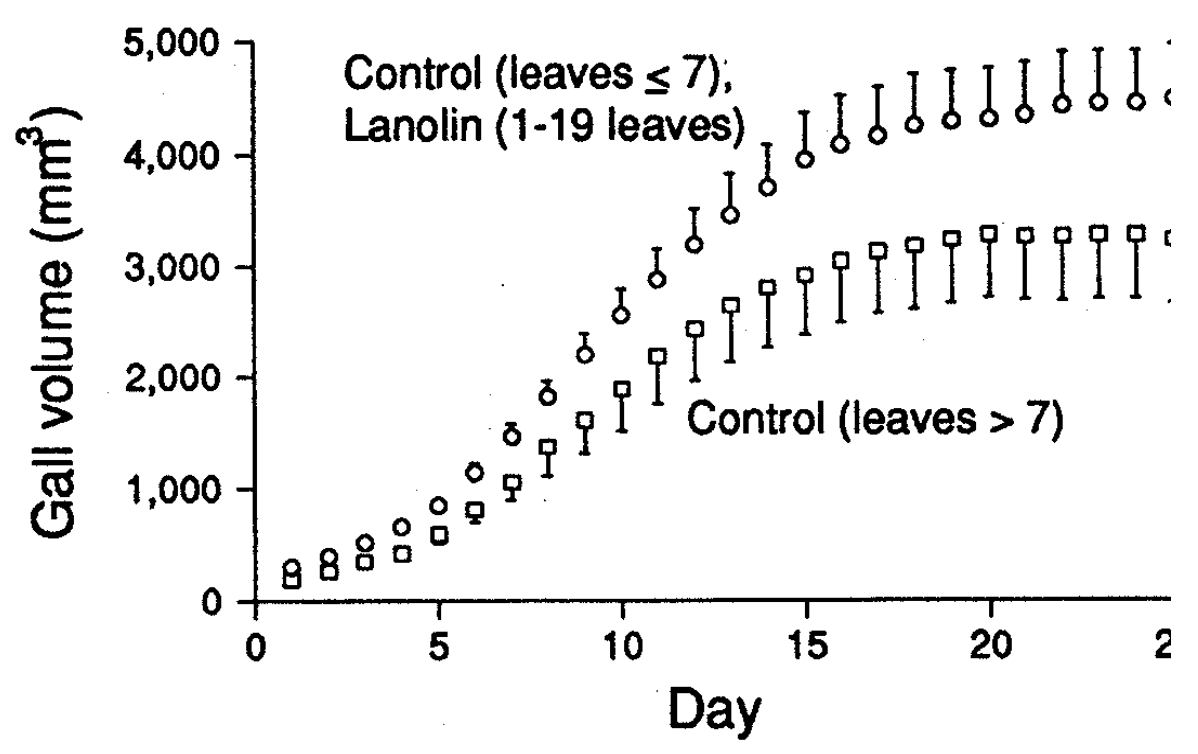

Fig. 13. Growth of Urophora cardui galls on Cirsium arvense stems. Untreated galls on stems with eight or more leaves vs. galls coated with lanolin on stems with 1-19 leaves plus untreated galls on stems with less than eight leaves.

Biocontrol value. The impact of $U$. cardui is affected by the age of the stem attacked. Thistle stems that were nearly mature when attacked were not significantly lighter than unattacked stems at the end of the summer (Peschken and Derby 1992). Similarly, Forsyth (1984) found no significant effect of galls on root weight or new ramet production in 27 -cm-tall thistles, but when stems $4-7 \mathrm{~cm}$ high were galled, there was a $25 \%$ reduction in fresh root weight. After 11 weeks, galled plants had only 0.25 ramets each compared with 4.25 ramets in the controls. Similarly, Peschken and Harris (1975) reported a reduction of $66 \%$ in fresh root weight, and $50 \%$ in ramet production, 53 days after initiation of a single gall on stems $13 \mathrm{~cm}$ tall. Several galls per stem produced larger effects.

Table 4. The effect of defoliation on galls of Urophora cardui.

\begin{tabular}{llcl}
\hline Treatment & & Mean $\pm \mathrm{SE}$ & $p>|\mathrm{T}|$ \\
\hline No. of larvae developed per plant & Defoliated & $8.71 \pm 1.23$ & \\
& Non-defoliated & $5.35 \pm 0.7$ & 0.01 \\
Total pupal weight $(\mathrm{g})$ per plant & Defoliated & $0.097 \pm 0.014$ & \\
& Non-defoliated & $0.052 \pm 0.007$ & 0.003 \\
Gall weight $(\mathrm{g})$ & Defoliated & $1.32 \pm 0.219$ & \\
& Non-defoliated & $1.06 \pm 0.145$ & not sig. \\
\hline
\end{tabular}


Unfortunately for biocontrol, the power of the gall of $U$. cardui as a metabolic sink suffers because it is induced too late, when most of the thistle height growth is complete and transpiration from the many leaves reduces gall turgor. Consequently, the galls do not grow as large, receive less assimilates, and develop smaller larvae than they would on younger plants. Also, the lack of drought adaptation mechanisms for maintaining turgor, such as the accumulation of potassium or a hairy surface, restricts the gall to moist and shaded sites on the Canadian prairies. Consequently, U. cardui is of little biocontrol value in most agricultural situations.

Subanguina pictidis (Kirj.) (Nematoda:Tylenchidae). Subanguina picridis is a nematode that induces bud, stem, and leaf galls on Russian knapweed, Acroptilon repens (L.) de Candolle. Galls range from small, pubescent protuberances on leaves to swollen and stunted stems that die in early summer. The nematode is endemic to ArmeniaTadzhikistan where its use for biocontrol was pioneered (Ivanova 1966; Kirjanova and Ivanova 1969). In Canada, S. picridis is established near Kamloops, BC, and there was a colony on the bank of the South Saskatchewan River near Leader, SK, until it was lost to erosion.

Acroptilon repens is a persistent herbaceous perennial introduced into Canada with Turkestan alfalfa seed in the early 1900's, but its spread is mostly by horizontal roots. Most infestations are on river benches in the dry regions of British Columbia, Alberta, and Saskatchewan where, on both irrigated and non-irrigated land, it forms stands of 1164 stems per square metre that displace other herbaceous plants. The weed is toxic to horses and difficult to control with herbicides. More details are given by Watson (1980).

Biology. The biology and host range of S. picridis were studied by Watson (1986a, 1986b, 1986c) who suggested that the Subanguina spp. described from Acroptilon, Cousinia, Rhaponticum, Centaurea, and Chartolepsis should be synonymized with S. picridis. Thus, the host range includes several genera in the tribe Centaureinae. The infective second-stage larvae of the nematode concentrate in the upper $5 \mathrm{~cm}$ of the soil in early spring: Ivanova (1966) reported densities of up to 140 larvae per gram of soil. When the humidity is high, the larvae climb the hairs on emerging stems and penetrate the meristem to induce a gall in 3-4 days, but host recognition is poor and larvae penetrate most plants including wheat, sunflower, bean, and tomato in which they are absorbed (Watson 1986a). The shoot-bud galls (Fig. 14), induced before the plant has leaves, start as small, whitish, hairy swellings with 5-55 nematodes of both sexes (Ivanova 1966). Numerous eggs are laid and by the end of the second generation in late August, there may be over 11,500 nematodes in a gall on a stunted-leafless stem. Galls that form later, after the plant has many leaves, remain small and develop few nematodes. The rust disease, Puccinia acroptili P. and H. Syd., was particularly dense on galls at Leader, SK, where it sporulated both on the gall exterior and inside the chamber without apparent harm to the nematode.

Second-stage larvae become dormant in mid-summer, the galls dry and eventually decay. The nematodes are revived by moisture and move into the soil. These pre-parasitic larvae have approximately half the proteolytic enzyme activity of the infective stage and they do not initiate galls until they have spent 6-7 weeks in moist soil, which in practice 
means they overwinter. Larvae can be stored dry for at least 10 years and become active within minutes when placed in water. However, under field conditions they disappear after 2 years in soil (Watson and Harris 1984). No natural enemies have been reported.

Development and structure of the gall. The structure of the gall on $A$. repens is well defined 7 days after larval penetration. The central chamber with the nematodes is interspersed with debris of collapsed cells (Fig. 15). Next, there is a layer of non-vacuolated, cytoplasmically dense nutritive cells, each with a large nucleus and two or three nucleoli. The nutritive tissue consists of a broad zone of tightly packed parenchyma that radiates from the vascular bundles to the epidermis. Cells of the epidermis are slightly enlarged and have extensive hair development. The central chamber enlarges slightly and becomes increasingly irregular with age, but the tissue zones are maintained until the gall dries up.

There are degrees of host suitability for S. picridis (Watson 1986a). On the best host, A. picridis, stems, buds, and leaves are galled and the galls have a broad, well-defined nutritive layer with little or no necrosis. On marginal hosts, the galls are confined to leaves, there is usually no nutritive tissue (but if present it is not arranged in a layer), and there is much necrosis. In tissue cultures of $A$. repens root tips, Ou and Watson (1992) found that the nematode did not induce galls or develop beyond the fourth larval stage. In stem callus on a high gibberellic acid culture medium, both males and females were produced, but they did not mate or produce eggs. However, they did so on shoot tips (Ou and Watson 1993) and the addition of gibberellic acid reduced developmental time from 6 to 4 weeks (Ou and Watson 1992).

Gall physiology. The high proteolytic activity in the infective larvae suggests that galls develop in response to enzymatic rather than mechanical damage. The stem galls of $S$. picridis have enlarged stomata and transpiration is increased. The width of the stomata opening on ungalled stems was $0.9 \pm 0.2(\mathrm{SE}) \mathrm{rm}$ compared with $3.9 \pm 0.2$ (SE) rm for those in the enlarged bud galls (determined as in Experiment 1, Appendix 1). The galled stems collected in late August lost $0.083 \pm 0.007$ (SE) $g$ at room temperature in 6 hours compared with $0.047 \pm 0.007$ (SE) $\mathrm{g}$ for those without galls (determined as in Experiment 2, Appendix 1). Thus, even at maturity, transpiration from the galls was 1.8 times that from an equivalent stem portion, so the early desiccation of attacked stems is not surprising.

The stem galls of both $U$. cardui and $S$. picridis increase transpiration, but the consequences are not the same. We suggest that a high potassium gradient (Tables 5 and 6) (Experiment 6, Appendix 1), which was not found in galls of the other species examined, allows the gall of $S$. picridis to be an assimilate sink under dry conditions (see Discussion). A high gradient of amino acids helps this process, and a high $\mathrm{N}$ level was found in the immature gall, although lost by July. Owens and Specht (1966) found that the rootknot galls of the nematode Meloidogyne incognita (Chitwood) (Nematoda:Tylenchida) had $20 \%$ more $\mathrm{K}$, about half the free sugars, and over three times the free amino acids of ungalled tissue.

Page 20 of 40 
Biocontrol value. Assimilates are diverted to the gall of $S$. picridis for about half the growing season and this often kills its host. Ivanova (1966) reported that over $90 \%$ of stems of $A$. repens inoculated with crushed gall material $\left(100 \mathrm{~g} / \mathrm{m}^{2}\right)$ were galled, nearly $20 \%$ of them died, and there was severe damage to another $30 \%$. At Regina, SK, in a series of dry years, less than $10 \%$ of the stems were galled, although continuous attack for 3 years killed the plants. On dry rangeland at Leader, SK, no galls were recovered, but at the edge of the South Saskatchewan River, where river fogs were common, shoots were often reduced to irregular galls $2 \mathrm{~cm}$ wide and $4 \mathrm{~cm}$ high. We conclude that infection by $S$. picridis requires high atmospheric humidity in the spring.

Subanguina picridis has been used little for biocontrol in North America, but it is promising for spring-moist and irrigated sites. The nematode can be used as a classical biocontrol agent or applied as a bioherbicide, and large numbers of nematodes can be obtained from field plots or increased 140- to 200-fold in 3 months on shoot tips of $A$. repens in tissue culture (Ou and Watson 1992).

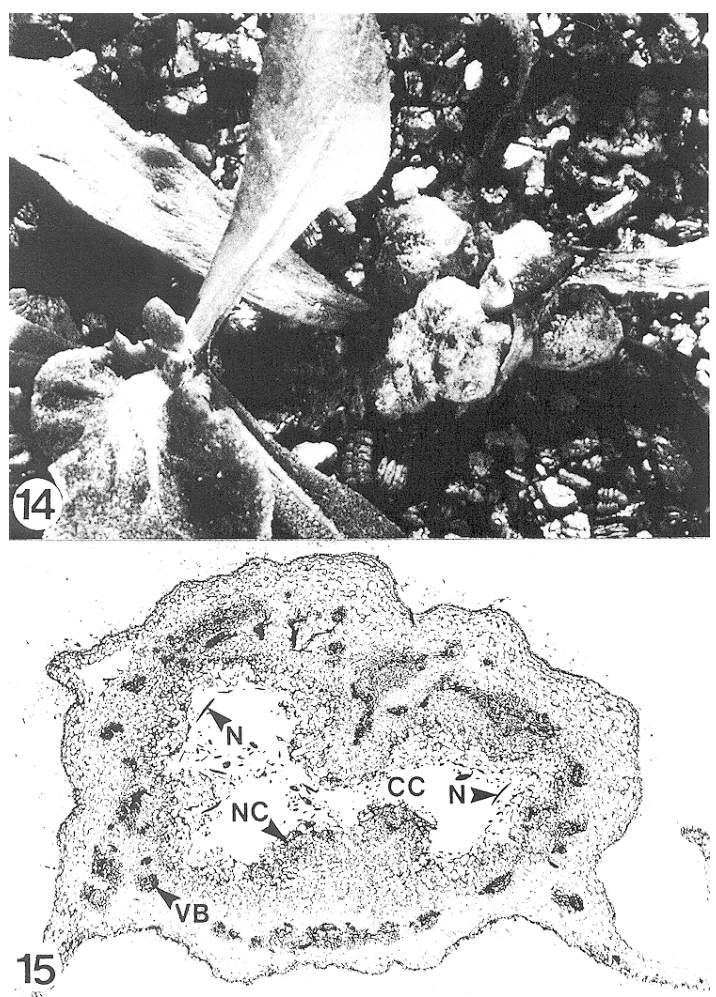

Figs. 14- 15. Leaf galls of Subanguina picridis on Acroptilon repens: 13, typical leaf galls; 14, gall on leaf, Safranin-fast green, $\times 10$. Abbreviations: $\mathrm{CC}$, central chamber; N, nematodes; NC, nutritive cells; VB, vascular bundles.

Table 5. Nitrogen and potassium content of galls of Subanguina picridis and ungalled stems of Acropti lonrepens.

\begin{tabular}{lccccc}
\hline & & \multicolumn{4}{c}{ Mean \% of dry tissue } \\
\cline { 3 - 6 } \multicolumn{1}{c}{ Tissue sample } & Date & $\mathrm{N}$ & $\mathrm{SE}$ & $\mathrm{K}$ & $\mathrm{SE}$ \\
\hline Stem (ungalled plants) & Late June & 1.07 & - & 2.33 & - \\
Stem (galled plants) & Late June & 0.83 & - & 2.00 & - \\
Stem next to the gall & Late June & 2.12 & - & 3.20 & - \\
Gall & Late June & 2.96 & - & 5.18 & - \\
Stem (ungalled) & Early August & $1.72 \mathrm{a}$ & 0.12 & $1.72 \mathrm{a}$ & 0.12 \\
Stem (galled) & Early August & $1.84 \mathrm{a}$ & 0.03 & $1.78 \mathrm{a}$ & 0.12 \\
Gall & Early August & $1.87 \mathrm{~b}$ & 0.79 & $2.12 \mathrm{a}$ & 0.12 \\
\hline
\end{tabular}

Means in a column with different letters are significantly different (Tukey's studentized range test, $p<0.05$ ). 
Table 6. Percentage potassium and nitrogen in stem and galls of Subanguina picridis in July.

\begin{tabular}{llccr}
\hline & Tissue & Mean $\%$ & SE & N \\
\hline \multirow{2}{*}{ Potassium } & Gall & $2.61 \mathrm{a}$ & 0.18 & 9 \\
& Stem & $2.04 \mathrm{~b}$ & 0.12 & 14 \\
& Gall & $2.13 \mathrm{a}$ & 0.24 & 9 \\
& Stem & $0.99 \mathrm{~b}$ & 0.07 & 14 \\
\hline
\end{tabular}

Means with different letters are significantly different (Tukey's studentized range test, $p<0.05$ ).

Urophora affinis (Frfld.) (Diptera: Tephritidae). Urophora affinis is a tephritid fly that forms a unilocular receptacle gall (Fig. 16) in the Centaurea subgenus Acrolophus, which contains the weeds $C$. diffusa and C. maculosa, diffuse and spotted knapweed. The fly is native to Europe (White and Komeyev 1989). French stock from C. valleseaca (DC.) Jordon was released in Canada in 1970 and later supplemented with Ukrainian stock from C. sterilis Steven. The fly is established in British Columbia, Ontario, and Quebec where its impact has been summarized by Harris and Myers (1984). Biology has been reported by Zwölfer (1970), Story (1976), Harris (1980a, 1980b), Myers and Harris (1980), and Berube (1980). The two knapweeds are described under U. quadrifasciata.

Biology. Adults of $U$. affinis start emerging with formation of the first knapweed capitula (mid-June in British Columbia), and emergence peaks in the 1st week of July, when the largest capitula are about $3 \mathrm{~mm}$ long. Up to 120 eggs per female are laid in groups of one to five on top of the tubular disc florets 3.5-5.5 mm long (half-grown capitula) (Berube 1980) over a 3-week period (Zwölfer 1970). Multiple oviposition is restricted by the 2-3 days during which a capitulum is acceptable and, in contrast to the requirements of $U$. quadrifasciata, pollination is unnecessary for gall development.

Eggs hatch in 3-4 days and the larvae tunnel down a floret to the receptacle surface where the gall is induced (Shorthouse 1989). Between 10 and 25\% of the larvae pupate by 33 days and may emerge for a second generation in August; however, most overwinter as larvae in the gall. Larvae successfully overwintered at Regina, SK, so that the potential range of $U$. affinis is wider than the present distribution of knapweed. Densities can exceed 3000 galls per square metre and levels of over 1000 galls per square metre are common in British Columbia (Harris 1980b).

Larval mortality in Europe from parasitoids in the genus Eurytoma and predation by Pyemotes sp. mites (Pyremotidae: Acarina) is usually over 50\% (Zwölfer 1970). The mites tend to attack other insects in the capitula and then spread to $U$. affinis through the open apex of the gall. Turner et al. (1990) found that $1.3 \%$ of the galls of $U$. affinis on spotted knapweed in Montana were parasitized by Microdontomerus anthonomi (Crawford) (Torymidae: Hymenoptera), which is usually associated with weevils. The largest mortality in Canada is on spotted knapweed from the seed-feeding moth M. paucipunctella, which consumed $67 \%$ of the larvae in a capitulum and commonly attacked $50-80 \%$ of the capitula (Story et al. 1991). With lower parasitism and higher knapweed density in Canada, the population of $U$. affinis on spotted knapweed is at least 3.5 times greater than that in Europe and, on diffuse knapweed, almost 19 times greater (Table 7). 
Table 7. Density of Urophora affinis in Canada and Europe.

\begin{tabular}{lcll}
\hline & No. of samples & No. of capitula & No. of $U$. affinis per capitulum \\
\hline $\begin{array}{l}\text { Spotted knapweed } \\
\quad\end{array}$ & 74 & $100-200$ each & $1.44 \pm 0.19$ (SE) \\
$\quad$ Canada & 45 & 4932 & $0.41 \pm 0.19$ (SE) \\
$\quad$ Europe & & & \\
$\begin{array}{l}\text { Diffuse knapweed } \\
\text { Canada }\end{array}$ & 26 & $100-200$ each & $0.62 \pm 0.1(\mathrm{SE})$ \\
$\quad \begin{array}{l}\text { Europe (excluding } \\
\text { France and Germany) }\end{array}$ & 55 & 8145 & $0.33 \pm 0.13$ (SE) \\
\begin{tabular}{l} 
France and Germany \\
\hline
\end{tabular} & 26 & 6258 & $0.005 \pm 0.016$ (SE) \\
\hline
\end{tabular}

Development and structure of the gall. Gall development was described by Shorthouse (1989). Freshly hatched larvae chew down a floret, consume the ovule, and then feed on the inner layer of the ovary wall. After about 12 days, they penetrate the base of the ovary to feed on the receptacle. Cells of the ovary wall and receptacle proliferate to enclose the larva in a thick layer of parenchyma. Vascular bundles extend from the receptacle into this layer which becomes nutritive tissue. The nutritive cells are thickest by about 25 days and, at about this time, a sclerenchyma layer forms around the gall except for the apex (Fig. 17). The larva feeds in an inverted position, but at the end of the fourth stadium it turns so the head is toward the sclerenchyma-free exit. Proliferation of the nutritive layer decreases with maturity and the larva, at about 28 days, is in a sclerenchyma-lined chamber.
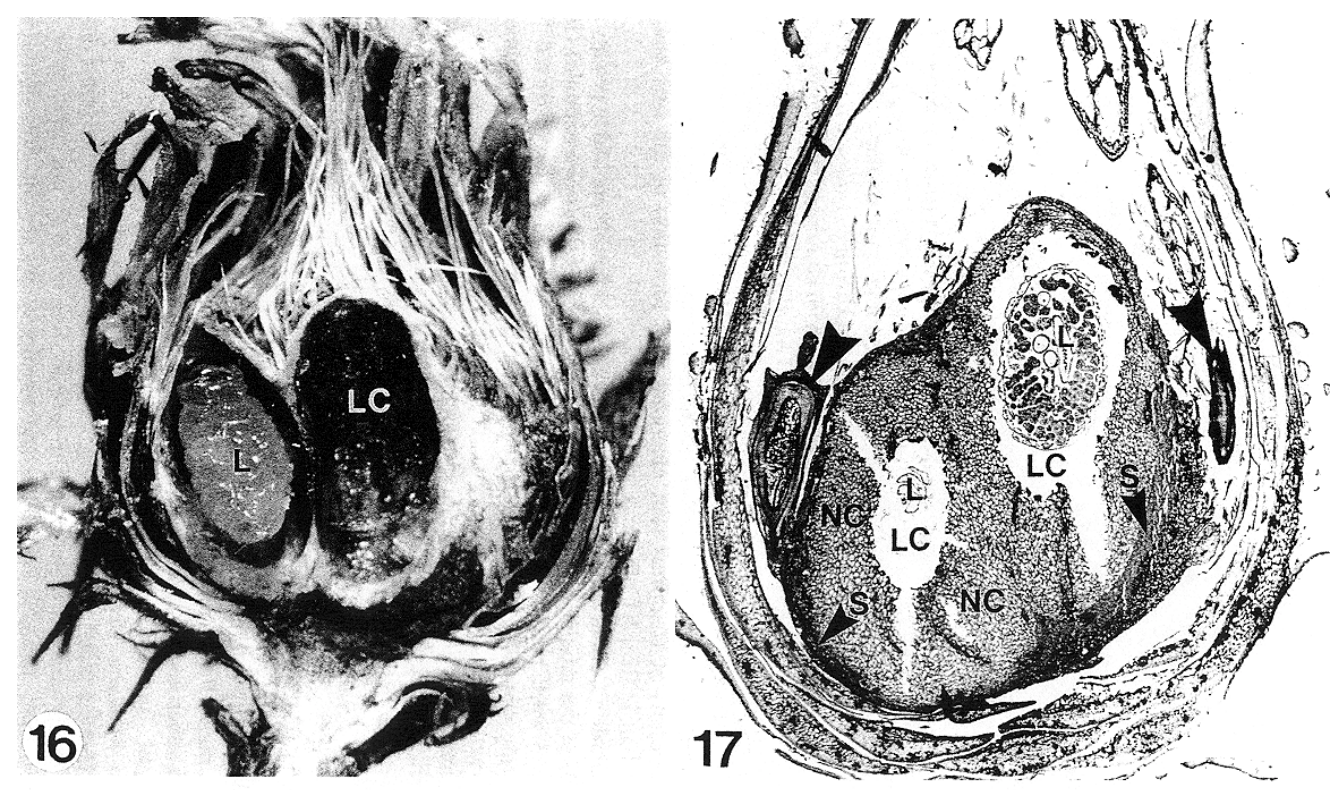

Figs. 16-17. Galls of Urophora affinis within capitula of Centaurea diffusa: 15, capitulum with two larval chambers on the receptacle surface, $\times 12 ; 16$, capitulum with two larvae surrounded by nutritive cells, sclerenchyma and aborted ovaries (arrows), Safranin-fast green, $\times$ 14. Abbreviations: L, larva; LC, larval chamber; NC, nutritive cells, S, sclerenchyma. 
Gall physiology. The developmental time of $U$. affinis is about half that of $U$. cardui, because it avoids the month-long period of gall growth and nutrient accumulation. Presumably this is possible because the receptacle, in which the gall is initiated, is already a nutrient sink. The nutrient sink of the gall is powerful enough that larval crowding in a capitulum has little effect on their weight (Harris 1980b). Mature larvae in their gall were, on average, $117 \mathrm{~kJ}$, and the value of the capitula increased directly with the number of larvae. The maximum number of galls that can develop is a function of the receptacle disc area, so more galls are produced in capitula of C. maculosa than in those of C. diffusa.

Much of the assimilate loss to the plant is represented by the gall shell. Each gall with a larva in spotted knapweed was, on average, $139 \mathrm{~kJ}$ and the mature larva was $66 \mathrm{~kJ}$, so the lignified shell represents about $47 \%$ of the loss to the plant. Gall lignin content, as determined in Experiment 5 (Appendix 1), was 17.4\% acid-insoluble and 1.1\% acidsoluble, so it is mainly saturated (double bonded), which indicates that the gall should be a less effective accumulator of toxins than that of $U$. cardui . The power of the gall as a metabolic sink makes it vulnerable to many herbicides. Story et al. (1988) reported that 2,4-D, applied to knapweed during the flower-bud and flowering stages, reduced the emergence of $U$. affinis. Similarly, the herbicide, picloram, at levels sublethal to the plant, reduces the galls to small woody lumps that produced no flies, and in less affected galls, fly size is reduced. Thus, the effects are similar to those of $U$. cardui's gall. Picloram did not affect the other two capitulum-inhabiting insects that do not form a gall shell, the gall-fly U. quadrifasciata (Table 1), or the non-gall moth M. paucipunctella.

The corolla is suppressed or absent in galled capitula and the stomata in the bracts are not enlarged, so transpiration losses from galled capitulum should be small. This is essential in a species of dry grasslands that lacks the elevated potassium levels of the gall of $S$. picridis. The gall $\mathrm{K}$ and $\mathrm{N}$ content was determined (Experiment 6, Appendix 1) by analysing capitula containing a known number of immature galls. The potassium content in galled capitula was $1.22 \pm 0.04 \%$ (SE) and $1.24 \pm 0.03 \%$ (SE) in the ungalled and did not increase with the number of galls. In contrast, the amount of nitrogen in the galled capitulum increased directly with the number of larvae (Table 8), so galling clearly increases the importation of nitrogen. According to Pate (1989), 97\% of the nitrogen acquired by fruits is phloem-supplied so it is likely similar in the gall.

Biocontrol value. The florets tunnelled by larvae of $U$. affinis are destroyed and adjacent ones abort. However, Harris (1980b) showed that the main impact was the suppression of subsequent capitula and vegetative growth. In $C$. diffusa, each gall reduced production by about 13.7 seeds, and an average of 1.1 galls per capitulum reduced the above-ground dry weight of the plant by $71 \%$ as well as the average seed weight. The seed displaced by a single larva represents $372 \mathrm{~kJ}$ and mature larvae were, on average, 42 $\mathrm{kJ}$. The damage ratio of 1:8.9 indicates an efficiency of less than one-third that of $U$. quadrifasciata. The more damage done by a weed biocontrol agent the better, so a low efficiency is desirable.

The combined effect of $U$. affinis, $U$. quadrifasciata, and $S$. jugoslavica at White Lake, BC, has been to reduce the number of capitula per square metre from 2100 in 1976 to 600 in 1988-1990 and seed production from around 33,000 to under 800 per square metre (Harris 1991). Roze (1981) determined that about 1500 seeds per square metre are 
needed on rangeland to maintain knapweed density, so seed production is now considerably below this level.

The effect on the polycarpic C. maculosa is different. Near Chase, BC, there was no reduction in the number of capitula or above-ground biomass in the year of attack because most growth is complete before fly emergence. However, after several years, there has been a decline in the number of capitula and seed production has dropped from over 40,000 per square metre to an average of just over 3000 per square metre in 1987-1990 (Harris 1991). Berube and Myers (1982) suggested that control might now be achieved by establishing a strong competitor of knapweed, such as crested wheatgrass. Without competition, Schirman (1981) found that knapweed seed reduction would have to be over $99.9 \%$ to achieve control.

In conclusion, $U$. affinis is the most important seed-reducing agent established on diffuse and spotted knapweed. As a result, knapweed seed production is close to the threshold needed to achieve economic control, which can be achieved by establishing another agent and increasing interplant competition in pastures.

\section{Discussion}

We suggest that the impact of gall inducers on the host plant is affected by three interacting variables. First is the abundance of the gall which we discuss in terms of vulnerability to parasitism and to moisture stress. Second, we discuss the power of the gall as a metabolic sink, which in turn depends on the method of gall induction, the extent of vascularization, and lignification. Third, we discuss the ability of a gall to exploit a nutritional resource and suggest that the gall has logistic advantages over non-gall inducers for using resources that are diffuse in space and time.

Vulnerability of gall inducers to parasitism. Parasitism or predation that causes a major reduction in population density of a gall inducer obviously affects its efficacy as a biocontrol agent. A high proportion of parasitoids of gall inducers are idiobionts (Hawkins 1990) (those that develop on a dead or paralysed host), which tend to have a wide host range (Comell and Hawkins 1993). The implication is that native parasitoids are likely to attack introduced gall inducers used for weed biocontrol, but the contrary seems to be true.

Native, generalist, parasitoids attack $19 \%$ of larvae of $R$. conicus boring in petioles of C. nutans and almost $16 \%$ of those in the small capitula of $C$. acanthoides. However, losses of larvae inhabiting capitula of $C$. nutans are small, so apparently the mass of the surrounding tissue offers protection from generalists. The parasitoid of $U$. cardui in Canada is an adventive introduction on another Urophora sp. It does not cause high losses of $U$. cardui in Europe and it kills only $8 \%$ of the larvae in Nova Scotia. Predation by the introduced knapweed-seed moth, M. paucipunctella, destroys up to half the larvae of $U$. affinis and $U$. quadrifas ciata, but the loss occurs after the larvae have completed feeding, so it does not reduce the current impact of the gall inducer and it is not large enough to reduce the size of the subsequent generation. Parasitism by native species of the other gall inducers, except by Cecidomyiidae, is inconsequential and seems to be the result of accidental encounters.

Page 25 of 40 
Table 8. Effect of Urophora afflnis on the nitrogen content of capitula of Centaurea maculosa.

\begin{tabular}{cc}
\hline No. of larvae per capitulum & \% nitrogen \\
\hline 0 & 1.24 \\
1 & 1.32 \\
$2-3$ & 1.45 \\
$4-5$ & 1.48 \\
$6-7$ & 1.74 \\
\hline
\end{tabular}

On a world basis, the only example we can find of major attack by native parasitoids on a non-cecidomyiid gall inducer used for weed control is that of the tephritid stem-gall inducer Procecidocharus utilis Stone, in Australia. This species is ineffective as a biocontrol agent with parasitism of generally more than $30-40 \%$ and often $70 \%$ (Goeden and Louda 1976).

Cecidomyiidae is apparently the only family of weed biocontrol agents that routinely suffers high enough losses from native parasitoids to compromise its effectiveness. For example, in Alberta the leaf-gall midge Cystiphora sonchi L. on S. arvense is so heavily parasitized that it is difficult to find (Peschken, pers. com.). There is a high rate of parasitism of the spurge bract-gall midge Spurgia esulae Gagné, in North Dakota (Carlson and Mundal 1990). Up to 95\% parasitism by Mesopolobus sp. of the late-season Cystiphora schmidti Rubsaamen reduces the midge's ability to control Chondrilla juncea L. in Washington State, but in Australia, parasitism by a native Tetrastichus sp. can reach 100\% (Wehling and Piper 1988). The leaf-gall midge Zeuxidiplosis giardi (Kieffer) is established, but of little consequence, in California (Julien 1992), and at low elevations in Australia with parasitism of $60-80 \%$ (Goeden and Louda 1976). The low parasitism on the still localized populations of Spurgia capitigena (Bremi) on cypress spurge in Ontario is exceptional, but may not persist.

Vulnerability of the gall to moisture stress. There are mixed reports in the literature on the vulnerability of galls to drought, although most suggest it is detrimental. Waring (1986) reported that gall diversity and abundance were greatest on plants growing in warm dry regions with an adequate water supply. Waring and Cobb (1992) reported that in $73 \%$ of studies, gall inducers reacted negatively to drought.

Assimilates are partitioned within a plant to utilization centres, but water deficit redirects translocation to unstressed sinks. For example, Robinson et al. (1983) found that, in moist conditions, the gladiolus inflorescence received most of the plant's assimilates; but with a slight water deficit, the corm accumulated assimilates at four times the rate of that in well-watered plants. Similarly, Fay et al. (1993) found that turgor in shoots galled by Antistrophus silphi Gil. (Hymenoptera: Cynipidae) was greater than that of ungalled shoots in drought-stressed, but not in well-watered, plants. As a result, in dry conditions, photosynthesis continued in leaves near the gall after ceasing in the rest of the plant.

Without adaptations for resisting water stress and with enlarged stomata, U. cardui fares poorly in dry conditions and on plants with many leaves. Thus, in southern Saskatchewan, the galls are found only near water, whereas in the humid and cloudy regions 
of western Europe, they are more widely distributed. The apparently poor adaptation of this insect to its host may be a consequence of evolutionary history: the genus Urophora evolved as capitular gall inducers (Zwölfer and Arnold-Rinehart 1993), in which gall induction does not enlarge the stomata and corolla reduction decreases water loss. Water is not limiting for the gall of $U$. cardui in the aquatic thistle C. creticum and high transpiration from the gall should increase its importation of nitrogen via the xylem. The fly does well on $C$. arvense in moist, forest-margin sites, but poorly in most places to which the thistle has been spread by agriculture. In contrast, the detrimental effects of enlarged stomata (inevitable in a gall induced in tissue with stomata) to the stem gall of the nematode $S$. picridis are moderated by two adaptations: a hairy surface, which is characteristic of many dry-region galls, and a high potassium content. The latter is similar to Australian mistletoes which commonly have enough potassium to increase turgor 3-8 bars over their host; one species has $39.0 \mathrm{mg} / \mathrm{kg}$ of potassium compared with $1.3 \mathrm{mg} / \mathrm{kg}$ for the host leaves (Lamont 1985). This allows the mistletoe to be an assimilate sink during drought (Ziegler 1986). Indeed, both mistletoes and galls with adaptations to maintain turgor may benefit from a moderate drought stress as resources are redirected to them from droughtstressed sinks.

Non-drought adapted galls without stomata apparently suffer with the plant during drought or periods of high transpiration from the leaves. For example, Dennill and Gordon (1990) reported that Trichilogaster acaciaelongifoliae (Froggatt) (Hymenoptera: Pteromalidae), which has a gall with no stomata and a largely riparian host, thrives only in the shade in the dry interior of South Africa. Larson and Whitham (1991) found that removing pistilate poplar catkins, which are both transpiration and nutrient sinks, increased the success of the gall aphid, Pemphigus betae Doane, by $31 \%$. Similarly, we found artificially reducing transpiration from galls improved the performance of $U$. car$d u i$. Hence, the establishment of a defoliator on $C$. arvense should increase the impact of $U$. cardui by reducing leaf transpiration.

Metabolic sink strength and gall induction. Galls always contain modified tissues, and usually produce new tissue that increases the nutrient supply for the inducer. The inducer initiates these modifications by mechanical or secretory damage. In both methods of induction, IAA is likely important, as it causes cell wall loosening, allowing expansion in response to turgor pressure maintained by solute influx (especially K) (Ray 1987) and this may be the basis of bract enlargement in the gall of T. dilacerata. All plant tissues produce callus (if the usually autonomously produced cytokinin is not limiting) with water, nutrients, and IAA (Wilson and Wilson 1991). IAA is produced by the catalysis of tryptophan (Kutacek 1991) from the autolysis of dead and dying cells (Sheldrake and Northcote 1968) and accumulates when basipetal polar transport in vascular tissue is interrupted. Thus severing vascular tissue in a nutrient sink (thistle receptacle and knapweed rosette root) should provide both the necessary IAA and nutrients for callus production. Severed xylem can serve as a moisture source providing flow can be restored after cutting, which requires enough moisture to exert a positive pressure. This hypothesis is consistent with the greater number of larvae of $R$. conicus found in secondary capitula in moist summers. Furthermore, drought can be expected to affect $S$. jugoslavica less than $R$. conicus, because root turgor in knapweed rosettes tends to be maintained by leaf senescence. A potential problem for the gall inducer is that plant tissue subjected to severe or prolonged damage is likely to die; however, this could be countered by an increase in

Page 27 of 40 
cytokinin, which has a strong nutrient-sink and anti-senescence activity. This idea is consistent with Hewett's (1977) finding of high cytokinin levels in the callus of the stem gall formed by Anetus virescens (Doubleday), a moth that requires up to 5 years to develop. We speculate that cytokinin in the gall of $R$. conicus is responsible for both the increased nutrient supply, the delayed senescence in both the bracts galled by $S$. arvensis and the staminate capitula of $C$. arvense, and for maintenance of the nutrient sink in the galled roots of $C$. diffusa.

The production of IAA in non-severance galls appears to be a plant response to damage from enzymes produced by the inducer, although $U$. cardui initiates gall induction by severing vascular tissue. According to references cited by Hori (1992), these contain the following tissue-damaging substances: the tephritid E. solidaginis secretes protease; the cecidomyiid Mayetiola destructor Say, hemicellulase; and the siricid Sirex noctilo F., amylase, esterase, phenol oxidase, and protease. IAA is necessary for protein synthesis in plants (Stuart 1938; Moorby 1977), so it is assumed to be needed for the production of nutritive tissue in galls.

Vascular differentiation requires about 10 times the amount of IAA optimum for callus growth, with phloem developing as a result of high IAA - high sugar levels and xylem from high IAA - low sugar levels (Wilson and Wilson 1991), so the reversal of these tissues during the growth of $U$. cardui's gall indicates a high IAA - high sugar concentration around the larvae. Sugar was not measured, but the IAA in U. cardui's gall is about three times that in the stems (Alexander 1987).

In our study, the galls with vascular systems were all induced while the host vascular system was developing. Thus, the gall of $U$. affinis, which is initiated in a young capitulum, develops a gall vascular system, but it is rudimentary in galls of $U$. quadrifasciata, which are initiated after vascular differentiation in the capitulum.

The inducer-host synchronization for vascular development in galls is achieved in various ways. Trichilogaster acaciaelongifolia oviposits into dormant buds at the end of summer; the larvae emerge, but do not develop until the buds reach the critical development stage in the spring (Dennill 1987). In U. affinis, in which oviposition does not occur until the buds have started development, synchronism is achieved by restricting oviposition to capitula that will be at the correct stage when the eggs hatch. This allows more room for a mismatch, which may explain the annual changes in the relative abundance of $U$. affinis and $U$. quadrifasciata. The larvae of $U$. cardui achieve synchronism by boring down the stem to the vascular differentiation zone; however, the system is not perfect in that attack of younger stems would provide the gall with a larger resource.

Synchrony is usually less critical in species not inducing vascular galls. For example, Phanacis taraxaci (Ashmead) (Hymenoptera: Cynipidae) induces galls in 1-cm to fully expanded leaves, although it prefers the immature (Paquette et al. 1993). However, there are exceptions, such as T. dilacerata, for which a flower-bud is available only for about 2 days because attack of younger buds leads to their abortion and the involucral bracts are not susceptible to modification in older capitula (Berube 1978a). In vascular-severance galls the oviposition window depends on the persistence of the nutritive sink: it is narrower in the temporary receptacular sink of thistle capitula than in the long-term sink of diffuse knapweed roots, which may last for several months. 
Lignification is essential for vascularization, so it should be found in any gall with vascular connections to its host. Lignin is formed from alcohols derived from phenylalanine (Bell 1981) and deposited during early secondary cell-wall thickening (Northcote 1972). It enables xylem to conduct water, provides rigidity by embedding cellulose fibre into a matrix, and binds metabolic wastes and many xenobiotic substances (Glasser and Kelley 1987) which include copper, zinc, iron, and nickel which were found in the shell by Bagatto et al. (1991) and Bagatto and Shorthouse (1991).

A lignified gall shell is similar to a seed coat because both have vascular tissue embedded in parenchyma of the surrounding shell and the nutrient supply is spatially and temporally distinct from the ovule or larval user. Indeed, nutrients are accumulated in the U. cardui gall before their use by the inducing larvae (Lalonde and Shorthouse 1985), much like the accumulation in receptacle tissue before ovule development. The main supply of these nutrients is phloem sap which has a carbon:nitrogen ratio of 15-200:1 (Pate 1980). Carbon is needed for cellulose formation during gall growth, but this need probably declines with gall maturation. A few cynipid galls secrete concentrated sugars (Bequaert 1924; Abe 1992) and surplus sugars may be exported via the phloem, as suggested earlier for the gall of $U$. cardui; but a more profitable use would be synthesis with ureides into amino acids. In seeds, phloem-imported ureides are synthesized into phenylalanine and tyrosine and then to amino acids, principally asparagine and glutamine, which are passed to the embryo (Thorne 1985). If the function of the gall shell is similar to that of a seed coat, it would provide both the high amino acid and IAA needed to form nutritive tissue, and to process any ureide wastes of the gall inducer into amino acids. The pathway for lignin synthesis is the same as that for aromatic amino acids except for the last steps (Neish 1960; Miflin and Lea 1977). In both seeds and galls there is rapid lignification at maturity, which we suggest results from switching production from aromatic amino acids to an inert substance, lignin, when the former are no longer needed. Extremely woody galls, such as that of $T$. acaciaelongifolia, have an extensive vascular system, so the degree of the gall lignification may be related to the strength of the gall as a metabolic sink.

In summary, we suggest the following largely new explanations. The induction of galls involves the local elevation of IAA which the inducer can elevate slightly by inflicting mechanical damage and particularly by severing vascular tissue. The severance of vascular tissue in a plant nutrient store normally produces substantial amounts of callus on which the inducer feeds. The impact of this type of gall increases with its persistence, which probably depends on a sustained level of cytokinin.

Gall inducers can cause a greater elevation of IAA, which is necessary for the development of new vascular tissue, by inflicting enzymatic damage. Vascularly supplied galls, which are powerful metabolic sinks, result from enzymatic damage done during vascular differentiation in the host tissue. We suggest that the pre-lignified shell of these galls synthesizes amino acids and hence helps nourish the inducer. It is likely that gall shell lignification at inducer maturity is the result of switching from amino acid synthesis, when it is no longer required, to lignin, an inert substance. For biocontrol, the more lignin produced the better, because it diverts assimilates from plant growth and reproduction.

Effectiveness of resource exploitation by gall inducers. The proof of a gall inducer's worth in weed biocontrol is the reduction in the domination of the plant commu- 
nity by the weed. The ability of the gall inducer to achieve such a change depends on a combination of the power of the gall as a sink, the distribution of the resource on the plant, and the abundance of the inducer.

It seems to us that the powerful-sink gall has a particular advantage for exploiting a resource that is produced in many small units over a long period, such as the capitula of C. diffusa. Logistically these are more difficult for a non-gall inducer to exploit than a resource concentrated into a few large capitula. Harris (1991) calculated that the receptacle gall fly Urophora solstitialis L. would reduce seed production by $50 \%$ more than would $R$. conicus in $C$. acanthoides, a thistle that produces many small capitula over a long season, but only $10-25 \%$ more in $C$. nutans, which produces fewer but larger capitula. In Italy, the main exploiters of the thistle Cynara scolymus L., which produces still larger and fewer capitula, are the non-gall weevils Larinus cynarae F. and L. scolymi Oliv. The gall fly $U$. terebrans Loew is comparatively uncommon (H. Zwölfer, pers. com. 1993). The justification for selecting gall inducers for biocontrol on this basis has still to be demonstrated, but Australian studies, cited by Woodburn (1993), suggest that the gall fly $U$. solstitialis would be superior to $R$. conicus for the biocontrol of $C$. nutans.

The vascular severance gall of $R$. conicus in the temporary nutrient sink of receptacle tissue obtains about $20 \%$ of its assimilates at the expense of later-developing capitula. In pistilate capitula of $C$. arvense, the importation of nutrients is likely greater than in $C$. nutans, but the sink is ephemeral, so the plant is affected only during a short part of the growing season. However, because $R$. conicus is abundant, well-synchronized with $C$. nutans flowering, and has little parasitism, it halves the seed production by $C$. nutans, but has less impact on $C$. acanthoides, which produces smaller capitula over a longer season. The vascular-severance gall induced by $S$. jugoslavica in the long-term nutrient store of diffuse knapweed rosette roots reduces seed production by about $50 \%$, but it does this at a lower agent density than required by $R$. conicus for a similar impact.

The galls induced by $T$. dilacerata and U. quadrifasciata develop little or no new vascular tissue so they are both dependent on the normal assimilate supply to the attacked capitulum. Mortality from natural enemies is not important in either species, but $U$. quadrifasciata is of biocontrol value as it has become abundant and supplements damage done by $U$. affinis. Even if T. dilacerata had become established in Canada, it is unlikely to have been of much biocontrol value because it is not abundant in Europe in spite of little parasitism.

The impact of galls with vascular connections to the host can be large. It was shown by Staden and Bennet (199 1) that the vascularly supplied stem gall of $P$. utilis changes assimilate partitioning and even increases the amount of nutrients delivered to the shoot above the gall. A total of 59\% of the assimilates from a leaf below the gall went to the gall and plant apex, $30 \%$ to the lower shoot, and $11 \%$ to the root. Partitioning in stems without galls, and in those with galls from which flies had emerged, was $21 \%$ to plant parts above the leaf, $53 \%$ to vegetative tissue below the leaf, and $26 \%$ to the root. This ability of galls with a vascular system to change partitioning has been well documented by Fourcroy and Braun (1967), Paclt and Hassler (1967), Jankiewicz et al. (1979), Skuhravy et al. (1980), McCrea et al. (1985), Brewer et al. (1987), Andersen and Mizell (1987), Larson and Whitham (1991), Hartley and Lawton (1992), and Paquette et al. (1993).

Page 30 of 40 
Unfortunately for the ease of selecting effective biocontrol agents, the nutrient diversion by galls with a vascular system varies widely. The unilocular tephritid stem gall of E. solidaginis on Solidago canadensis L. utilises about $7 \%$ of ramet net production (Stinner and Abrahamson 1979). The multilocular receptacle gall of $U$. stylata reduces seed production of Cirsium vulgare (Savi.) Ten. by about 60\% (Harris and Wilkinson 1984) and accounts for $85 \%$ of the caloric loss from the capitula if the lignified gall tissues are included (Zwölfer 1985). Multiple attacks by the unilocular gall of $U$. affinis reduce knapweed seed production by at least $75 \%$, whereas the bud-gall wasp T. acaciaelongifoliae, on less than $50 \%$ of the branches of its host, reduces seed production by $89-95 \%$ (Dennill 1988). Galls of the latter species contain up to 23 times the energy normally spent on seed production, and vegetative growth ceases during gall development, with the result that the gall accounts for $21 \%$ of annual dry biomass production by the tree (Dennill 1988).

\section{Conclusions}

1. To have a major impact on the target weed, galls should be powerful metabolic sinks. The most effective galls induced by severing vascular tissue persist over most of the growing season. The most effective galls with a vascular system develop a heavily lignified shell.

2. Gall inducers are particularly advantageous for exploiting a resource, like diffuse knapweed capitula, which is divided between many small centres over a long season.

3. Stomata on a gall are likely to be detrimental in dry sites, although they may be beneficial if moisture is not limiting. Some galls with hairy surfaces and high potassium levels are adapted to dry conditions and may benefit from moderate water stress that reduces translocation to competing sinks.

4. Except for gall midges, parasitism is generally not a problem for gall inducers introduced as weed biocontrol agents.

\section{Acknowledgments}

We gratefully acknowledge the following individuals: from the Regina Research Centre, Agriculture and Agri-Food Canada, G. McIntyre for discussions on resource partitioning in plants and A. Paton for technical assistance with experiments; from the Lethbridge Research Centre, V. Sewalt for analysing gall lignin, S. Lutwick for N, P, K analysis of galls, R. Brandt for statistical analysis, H. McMenamin and K. Floate for reviewing the manuscript, and S. Torgunrud for preparing the graphs; E. Schlichting of the Swift Current Research Centre for N, P, K analysis of galls; D. Pearce of the University of Lethbridge for discussion on plant hormone physiology; G. Bagatto of Laurentian University for discussions on host damage by gall insects. Research grants from the Natural Sciences and Engineering Research Council of Canada and the Laurentian University Research fund awarded to JDS are gratefully acknowledged. 


\section{References}

Abe, Y. 1992. The advantage of attending ants and gall aggregation for the gall wasp Andricus symbioticos (Hymenoptera: Cynipidae). Oecologia 89:166-167.

Abrahamson, W. G. and K. D. McCrea. 1986. Nutrient and biomass allocation in Solidago altissima: Effects of two stem gallmakers, fertilization, and ramet isolation. Oecologia 68:174-180.

Abrahamson, W. G. and A. E. Weis. 1987. Nutritional ecology of arthropod gall-makers. pp. 235-258 in Slansky, R. and G. Rodriguez (Eds.), Nutritional Ecology of Insects, Mites and Spiders. Wiley, New York, NY.

Alexander, A. 1987. Compatibility of Picloram and the Tephritid Fly Urophora cardui for Canada Thistle (Cirsium arvense L.) Control. M. Sc. thesis, University of Saskatchewan, Saskatoon, SK. 95 + viii pp.

Andersen, P. C., and R. F. Mizell. 1987. Physiological effects of galls induced by Phyloxera notabilis (Homoptera: Phyloxeridae) on pecan foliage. Environmental Entomology 16:264-268.

Bagatto, G., and J. D. Shorthouse. 1991. Accumulation of copper and nickel in plant tissues and an insect gall of lowbush blueberry, Vaccinium angustifolium, near an ore smelter at Sudbury, ON, Canada. Canadian Journal of Botany 69:1483-1490.

Bagatto, G., T. J. Zmijowskyj, and J. D. Shorthouse. 1991. Galls induced by Diplolepis spinosa influence distribution of mineral nutrients in the shrub rose. Hort Science 26: 1283 - 1284.

Bequaert, J. 1924. Galls that secrete honeydew. A contribution to the problem as to whether galls are altruistic adaptations. Bulletin of the Brooklyn Entomological Society 19:101-124.

Bell, A. A. 1981. Biochemical mechanisms of disease resistance. Annual Review of Plant Physiology 32:21-81.

Berube, D. E. 1978a. The basis for host plant specificity in Tephritis dilacerata and T. formosa (Dipt:Tephritidae). Entomophaga 23:331-337.

Berube, D. E. 1978b. Larval descriptions and biology of Tephritis dilacerata (Dip.: Tephritidae), a candidate for the biocontrol of Sonchus arvensis in Canada. Entomophaga 23: 69-82.

Berube, D. E. 1980. Interspecific competition between Urophora affinis and U. quadrifasciata (Diptera: Tephritidae) for ovipositional sites on diffuse knapweed (Centaurea diffusa: Compositae). Zeitschrift für Angewandte Entomologie 90:299-306.

Berube, D. E., and J. H. Myers. 1982. Suppression of knapweed invasion by crested wheatgrass in the dry interior of British Columbia. Journal of Range Management 35: 459-461.

Bronner, R. 1992. The role of nutritive cells in the nutrition of cynipids and cecidomyiids. pp. 118-140 in Shorthouse, J. D., and O. Rohfritsch (Eds.), Biology of Insect-induced Galls. Oxford University Press, New York, NY.

Brewer, J. W., J. N. Bishop, and V. Skuhravy. 1987. Levels of foliar chemicals in insect-induced galls (Dipt., Cecidomyidae). Zeitschrift für Angewandte Entomologie 104:503-510.

Carlson, R. B., and D. Mundal. 1990. Introduction of insects for the biological control of leafy spurge in North Dakota. North Dakota Farm Research 47(6):7-8.

Cornell, H. V., and B. A. Hawkins. 1993. Accumulation of native parasitoids on introduced herbivores: A comparison of hosts as natives and host invaders. The American Naturalist 141:847-865.

Crawley, M. J. 1989. The successes and failures of weed biocontrol using insects. Biocontrol News and Information 10:213-223.

Dennill, G. B. 1987. The Biological Control of the Weed Acacia Longifolia by the Gall Wasp Trichilogaster acaciaelongifoliae: A Study of a Plant-Insect Interaction. Ph. D. thesis, University of Cape Town, Cape Town. 468 pp. 
Dennill, G. B. 1988. Why a gall former can be a good biocontrol agent: The gall wasp Trichilogaster acaciaelongifoliae and the weed Acacia longifolia. Ecological Entomology 13:1-9.

Dennill, G. B., and A. J. Gordon. 1990. Climate-related differences in the efficacy of the Australian gall wasp Trichilogaster acaciaelongifolia (Hymenoptera:Pteromalidae) released for the control of Acacia longifolia in South Africa. Environmental Entomology 19:130-136.

Dowd, P. F., and L. T. Kok. 1982. Parasitism of Rhinocyllus conicus in Virginia. Environmental Entomology 11:71-77.

Dreger-Jauffret, F. and J. D. Shorthouse. 1992. Diversity of gall inducing insects and their galls. pp. 8-33 in Shorthouse, J. D., and O. Rohfritsch (Eds.), Biology of Insect-induced Galls. Oxford University Press, New York, NY.

Fay, D., C. D. Harnett, and A. K. Knapp. 1993. Increased photosynthesis and water potentials in Siphium integrifolium galled by cynipid wasps. Oecologia 93:114-120.

Forsyth, S. F. 1984. Stress Physiology and Biological Control of Canada Thistle, Cirsium arvense (L.) Scop. Ph.D. thesis, McGill University, Montreal, PQ. 330 pp.

Fourcroy, M. and C. Braun. 1967. Observations sur la galle de l'Aulax glechomae L. on Glechoma hederaceae L. II Histologie et rôle physiologique de la coque sclérifée. Marcellia 34:3-30.

Glasser, W. G. and S. S. Kelley. 1987. Lignin. Encyclopedia of Polymer Science and Engineering 8:795-852.

Goeden, R. D. and S. M. Louda. 1976. Biotic interference with insects imported for weed control. Annual Review of Entomology 21:325-342.

Graham, M. W. R. de V. 1969. The Pteromalidae of North Western Europe (Hymenoptera: Chalcidoidea). Bulletin of the British Museum (Natural History) Entomology Supplement. 352 pp.

Harris, P. 1979. The cost of biological control of weeds by insects in Canada. Weed Science 27:242-250.

Harris, P. 1980a. Establishment of Urophora affinis Frfld. and U. quadrifasciata (Meig.) in Canada for the biological control of diffuse and spotted knapweed. Zeitschrift für Angewandte Entomologie 89:504-514.

Harris, P. 1980b. Effects of Urophora affinis Frfld. and U. quadrifasciata (Meig.) (Diptera: Tephritidae) on Centaurea diffusa Lam. and C. maculosa Lam. (Compositae). Zeitschrift für Angewandte Entomologie 90:190-210.

Harris, P. 1991. Classical biocontrol of weeds: Its definition, selection of effective agents, and administrative-political problems. The Canadian Entomologist 123:827-849.

Harris, P. and R. Cranston. 1979. An economic evaluation of control methods for diffuse and spotted knapweed in western Canada. Canadian Journal of Plant Science 59:375-382.

Harris, P., and J. H. Myers. 1984. Centaurea diffusa Lam. and C. maculosa Lam. s. lat., diffuse and spotted knapweed (Compositae). pp. 127-137 in Kelleher, J. S., and M. A. Hulme (Eds.), Biological Control Programmes Against Insects and Weeds in Canada 1969-1980. Commonwealth Agricultural Bureaux, Farnham Royal, UK.

Harris, P. and A. T. S. Wilkinson. 1984. Cirsium vulgare (Savi) Ten., bull thistle (Compositae). pp. 147-153 in Kelleher, J.S., and M.A. Hulme (Eds.), Biological Control Programmes Against Insects and Weeds in Canada 1969-1980. Commonwealth Agricultural Bureaux, Farnham Royal, UK.

Hartley, S. E., and J. H. Lawton. 1992. Host-plant manipulation by gall-insects: A test of the nutrition hypothesis. Journal of Animal Ecology 61: 113-119.

Hawkins, B. A. 1990. Global patterns of parasitoid assemblage size. Journal of Animal Ecology 59:57-72.

Hendel, F. 1927. Trypetidae. In Lindner, E. (Ed.), Die Fliegen der palaearktischen Region. Stuttgart Vol. 5, pp. $1-221+17 \mathrm{pl}$.

Page 33 of 40 
Hewett, E. W. 1977. Some effects of infestation on plants: A physiological viewpoint. The New Zealand Entomologist 6:235-243.

Hori, K. 1992. Insect secretions and their effect on plant growth, with special reference to hemipterans. pp. 157-170 in Shorthouse, J. D., and O. Rohfritisch (Eds.), Biology of Insect-induced Galls. Oxford University Press, New York, NY.

Ivanova, T. S. 1966. Biological control of mountain bluet (Acroptilon picridis C.A.M.). Izvestiya Academil Nauk Tadzhikoi SSR 2:51-63. [In Russian. Translation-Translation Bureaux, Canadian Secretary of State No. 3793.]

Jankiewicz, L. S., H. Plich, and R. Antoszewski. 1979. Preliminary studies on the translocation of ${ }^{14} \mathrm{C}$-labelled assimilates and ${ }^{32} \mathrm{PO}_{4}{ }^{3-}$ towards the gall evoked by Cynips (Diplolepis) quercus-folii L. on oak leaves. Marcellia 36:163-174.

Jenson, E. A. 1984. Data requirements for economic evaluation of a knapweed containment program. pp. 27-36 in Lacey, J.R., and P.K. Fay (Eds.), Proceedings of the Knapweed Symposium, Montana State University, Bozeman, MT.

Johnston, T. H., and H. Tryon. 1914. Queensland: Report of the prickly-pear travelling commission, 1 November 1912 - 30 April 1914. Government Printer, Brisbane, Australia. 131 pp.

Julien, M. H. 1992. Biological Control of Weeds. A World Catalogue of Agents and their Target Weeds, 3rd ed. CAB International, Wallingford. $186 \mathrm{pp}$.

Kaar, W. E., L. G. Cool, M. M. Merriman, and D. L. Brink. 1991. The complete analysis of wood polysaccharides using HPLC. Journal of Wood Chemistry and Technology 11:447-463.

Kirjanova, E. S., and T. S. Ivanova. 1969. New species of Paranguina Kirjanova, 1955 (Nemotoda: Tylenchidae) on Tadzhikskoi. Ushcel's Kondara (Akademi Nauk Tadzhikskoi SSR) 2:200-217. [In Russian. Translation-Translation Bureaux, Canadian Secretary of State.]

Klein, M. and A. Seitz. 1994. Geographic differentiation between populations of Rhinocyllus conicus Frölich (Coleoptera, Curculionidae)-concordance of allozyme and morphometric analysis. Zoological Journal of the Linnean Society 110:181-191.

Kok, L. T., and W. W. Surles. 1975. Successful biocontrol of musk thistle by an introduced weevil, Rhinocyllus conicus. Environmental Entomology 4:1025-1027.

Küster, E. 1911. Die Gallen der Pflanzen. Ein Lehrbuch der Botaniker und Entomologen. Hirzel Leizig.

Kutacek, M. 1991. Plant hormones as factors of morphogenesis and structural integrity in plants. pp. 13-117 in Sebanek, J., Z. Sladky, and Prochazka (Eds.), Experimental Morphogenesis and Integration of Plants. Elsevier, Amsterdam.

Lalonde, R. G., and J. D. Shorthouse. 1982. Exit strategy of Urophora cardui (Diptera: Tephritidae) from its gall on Canada thistle. The Canadian Entomologist 114:873-878.

Lalonde, R. G., and J. D. Shorthouse. 1984. Developmental morphology of the gall of Urophora cardui (Diptera, Tephritidae) in the stems of Canada thistle (Cirsium arvense). Canadian Journal of Botany 62:1372-1384.

Lalonde, R. G., and J. D. Shorthouse. 1985. Growth and development of larvae and galls of Urophora cardui (Diptera: Tephritidae) on Cirsium arvense (Compositae). Oecologia 65:161-165.

Lamont, B. 1985. Host distribution, potassium content, water relations and control of two co-occurring mistletoe species. Journal of the Royal Society of Western Australia 68:21-25.

Larson, K. C., and T. G. Whitham. 1991. Manipulation of food resources by a gall-forming aphid: The physiology of sink-source interactions. Oecologia 88:15-21.

Lichter, J. P., A. E. Weis, and C. R. Dimmick. 1990. Growth and survivorship differences in Eurosta (Diptera: Tephritidae) galling sympatric host plants. Environmental Entomology 19:972-977. 
Littlefield, J. L. 1991. Parasitism of Rhinocyllus conicus Froelich (Coleoptera: Curculionidae) in Wyoming. The Canadian Entomologist 123:929-932.

Marsden, J. S., G. E. Martin, D. J. Parham, T. J. Riddsdill-Smith, and B. G. Johnston. 1980. Returns on Australian Agricultural Research. Industries Assistance Commission, C.S.I.R.O., Canberra. 107 pp.

McCrea, K. D., W. G. Abrahamson, and A. E. Weis. 1985. Goldenrod ball gall effects on Solidago altissima: ${ }^{14} \mathrm{C}$ translocation and growth. Ecology 66:1902-1907.

Mead, R., and R. N. Curnow. 1983. Statistical Methods in Agriculture and Experimental Biology. Chapman and Hall Ltd., New York, NY. 335 pp.

Meyer, J., and H. J. Maresquelle. 1983. Anatomie des galles. Gebrüder Borntraeger, Stuttgart. 662 pp.

Miflin, B. J., and P. J. Lea. 1977. Amino acid metabolism. Annual Review of Plant Physiology 28:299-329.

Moorby, J. 1977. Integration and regulation of translocation within the whole plant. pp. 425-454 in Jennings, E.H. (Ed.), Integration of Activity in the Higher Plant. Cambridge University Press, Cambridge.

Muesebeck, C. F. W., K. V. Krombein, and H. K. Townes. 1951. Hymenoptera of America North of Mexico. USDA, Washington, DC. 1420 pp.

Myers, J. H., and P. Harris. 1980. Distribution of Urophora galls in flower heads of diffuse and spotted knapweed in British Columbia. Journal of Applied Ecology 17:359-367.

Neish, A. C. 1960. Biosynthetic pathways of aromatic compounds. Annual Review of Plant Physiology 11:55-80.

Northcote, D. H. 1972. Chemistry of the plant cell wall. Annual Review of Plant Physiology 23:113-132.

$\mathrm{Ou}, \mathrm{X}$. and A. K. Watson. 1992. In vitro culture of Subanguina picridis in Russian knapweed callus, excised roots and shoot tissues. Journal of Nematology 24:199-204.

$\mathrm{Ou}, \mathrm{X}$. and A. K. Watson. 1993. Mass culture of Subanguina picridis and its bioherbicidal efficacy on Acroptilon repens. Journal of Nematology 25:89-94.

Owens, R. G., and H. N. Specht. 1966. Biochemical alterations induced in host tissues by root-knot nematodes. Contribution from Boyce Thompson Institute 23:181-198.

Pach, J., and J. Hassler. 1967. Concentration of nitrogen in some plant galls. Phyton 12:173-176.

Paquette, L. C., G. Bagatto, and J. D. Shorthouse. 1993. Distribution of mineral nutrients within the leaves of common dandelion (Taraxacum officinales) galled by Phanacis taraxaci (Hymenoptera: Cynipidae). Canadian Journal of Botany 71:1026-1031.

Pate, J. S. 1980. Transport and partitioning of nitrogenous solutes. Annual Review of Plant Physiology 31:313-340.

Pate, J. S. 1989. Synthesis, transport and utilization of products of symbiotic nitrogen fixation. pp. 65-134 in Oulton, J. E., J. T. Romeo, and E. E. Conn (Eds.), Plant Nitrogen Metabolism. Recent Advances in Phytochemistry. Plenum Press, New York, NY.

Patrick, J. W. 1984. Photosynthetic unloading from seed coats of Phaseolus vulgaris L.: Control by tissue water relations. Journal of Plant Physiology 115:297-310.

Peschken, D. P. 1984. Sonchus arvensis L., perennial sow-thistle, S. oleraceus L., annual sow-thistle and S. asper (L.) Hill, spiny annual sow-thistle (Compositae). pp. 205-209 in Kelleher, J. S., and M. A. Hulme (Eds.), Biological Control Programmes Against Insects and Weeds in Canada 1969-1980. Commonwealth Agricultural Bureaux, Farnham Royal, UK.

Peschken, D. P. 1990. The west is best-but not for Urophora cardui, (Tephritidae) a gall fly established in SK on Canada thistle. Proceedings of the Entomological Society of Saskatchewan 38:30. 
Peschken, D. P., and J. L. Derby. 1992. Effect of Urophora cardui (L.)(Diptera: Tephritidae) and Ceutorhynchus litura (F.) (Coleoptera:Curculionidae) on the weed Canada thistle, Cirsium arvense (L.) Scop. The Canadian Entomologist 124:145-150.

Peschken, D. P., and P. Harris. 1975. Host specificity and biology of Urophora cardui (Diptera: Tephritidae). A biocontrol agent for Canada thistle (Cirsium arvense). The Canadian Entomologist 107:1101-1110.

Peschken, D. P., and G. R. Johnson. 1979. Host specificity and suitability of Lema cyanella (Coleoptera: Chrysomelidae), a candidate for the biological control of Canada thistle (Cirsium arvense). The Canadian Entomologist 111:1059-1068.

Peschken, D. P., A. G. Thomas, and R. F. Wise. 1983. Loss in yield of rapeseed (Brassica napus, B. campestris) caused by perennial sowthistle (Sonchus arvensis) in SK and MB. Weed Science. 31:740-44.

Philipson, W. R. 1942. Studies in the development of the inflorescence. 1. The capitulum of Bellis perennis L. Annals of Botany (London) 10:257-270.

Powell, R. D., and J. H. Myers. 1988. The effect of Sphenoptera jugoslavica Obenb. (Col., Bupresitidae) on its host plant Centaurea diffusa Lam. (Compositae). Journal of Applied Entomology 106:25-45.

Ray, P. M. 1987. Principles of plant cell expansion. pp. 1-17 in Cosgrove, D. J., and D. P. Knievel (Eds.), Physiology of Cell Expansion During Plant Growth. American Society of Plant Physiologists, Rockville.

Robinson, M.A.H., Halevy, D. Galili, and Z. Plaut. 1983. Distribution of assimilates in Gladiolus grandiflorus as affected by water deficit. Annals of Botany 51:461-468.

Roitberg, B.D. 1988. Comparative flight dynamics of knapweed gall flies Urophora quadrifasciata and U. affinis (Diptera: Tephritidae). Journal of the Entomological Society of British Columbia 85:58-64.

Rowe, D. J., and L. T. Kok. 1984. Potential of Rhinocyllus conicus to adapt to plumeless thistle, Carduus acanthoides, in Virginia. Virginia Journal of Science 35:192-196.

Roze, L. D. 1981. The Biological Control of Centaurea diffusa Lam. and C. maculosa Lam. by Urophora affinis Frauenfeld and U. quadrifasciata Meigen (Diptera: Tephritidae). Ph.D. thesis, University of British Columbia, Vancouver, BC. 208 pp.

Sampson, M. G., and A. Ingraham. 1990. Biological Control of Weeds in Nova Scotia. Nova Scotia Department of Agriculture and Marketing, Halifax, NS. 53 pp.

Schirman, R. 1981. Seed production and spring seedling establishment of diffuse and spotted knapweed. Journal of Range Management 34:45-47.

Schroeder, D. 1974. The phytophagous insects attacking Sonchus spp. (Compositae) in Europe. pp. 89-96 in Wapshere, A. J. (Ed.), Proceedings of the 3rd International Symposium on Biological Control of Weeds. Commonwealth Agricultural Bureaux, Farnham Royal, UK.

Seitz, A., and M. Komma. 1984. Genetic polymorphism and its ecological background in tephritid populations (Diptera: Tephritidae). pp. 143-158 in Wohrman, K., and V. Lordchke (Eds.), Population Biology and Evolution. Springer-Verlag, Berlin.

Sheldrake, A. R., and D. H. Northcote. 1968. The production of auxin by autolysing tissues. Planta $80: 227-236$.

Shorthouse, J. D. 1980. Modification of the flower heads of Sonchus arvensis (family Compositae) by the gall former Tephritis dilacerata (order Diptera, family Tephritidae). Canadian Journal of Botany 58:1534-1540.

Shorthouse, J. D. 1989. Modification of flowerheads of diffuse knapweed by the gall inducer Urophora affinis and U. quadrifasciata (Diptera: Tephritidae). pp. 221-228 in Delfosse, E.S. (Ed.), Proceedings of the VII International Symposium on Biological Control of Weeds, Instituto Sperimentale per la Patologia Vegetale, Rome. 
Shorthouse, J. D., and R. G. Lalonde. 1984. Structural damage by Rhinocyllus conicus (Coleoptera: Curculionidae) within the flowerheads of nodding thistle. The Canadian Entomologist 116:1335-1343.

Skuhravy, V., M. Skuhravy, and J. W. Brewer. 1980. Evaluation of plant damage caused by 3 species of gall midges (Diptera: Cecidomyiidae). Zeitschrift für Angewandte Entomologie 90:184-190.

Staden, van J., and P. H. Bennet. 1991. Effect of galling on assimilate partitioning in crofton weed (Ageratina adenophora). South African Journal of Botany 57:128-130.

Stinner, B. R., and W. G. Abrahamson. 1979. Energetics of the Solidago canadensis-stem gall insectparasitoid guild interaction. Ecology 60: 918-926.

Story, J. M. 1976. A Study of Urophora affinis (Diptera: Tephritidae) Released on Spotted Knapweed in Western Montana. M. Sc. thesis, Montana State University, Bozeman, MT. 1-77 pp.

Story, J. M., K. W. Boggs, and W. R. Good. 1988. Optimal timing of 2,4-D applications for compatibility with Urophora affinis and U. quadrifasciata (Diptera: Tephritidae) for control of spotted knapweed. Environmental Entomology 17:911-914.

Story, J.M., K.W. Boggs, W.R. Good, P. Harris, and R.M. Nowierski. 1991. Metzneria paucipunctella Zeller (Lepidoptera:Gelechiidae), a moth introduced against spotted knapweed: Its feeding strategy and impact on two introduced Urophora spp. (Diptera: Tephritidae), The Canadian Entomologist 123: 1001-1007.

Story, J. M., R. M. Nowierski, and K. W. Bogs. 1987. Distribution of Urophora affinis and U. quadrifasciata, two flies introduced for biological control of spotted knapweed (Centaurea maculosa) in Montana. Weed Science 35:145-148.

Stuart, N. W. 1938. Nitrogen and carbohydrate metabolism of kidney bean cuttings as affected by treatment with indoleacetic acid. Botanical Gazette 100:298-311.

TAPPI. 1989. Acid-soluble Lignin in Wood and Pulp, Useful Method 250. Technical Association of the Pulp and Paper Industry, Atlanta, GA. 2 pp.

Thibodeau, P. D. 1985. Translocation of ${ }^{14} \mathrm{C}$-labelled Assimilates in the Urophora cardui (L.) (Diptera:Tephritidae) - Cirsium arvense (L.) Scop. (Compositae) Gall System. M. Sc. thesis, Laurentian University, Sudbury, ON. 115 pp.

Thorne, J. H. 1985. Phloem unloading of C and N assimilates in developing seeds. Annual Review of Plant Physiology 36:317-343.

Turner, C. T., E. E. Grissell, J. P. Cuda, and K. Casanave. 1990. Microdontomerus anthonomi (Crawford) (Hymenoptera: Torymidae), an indigenous parasitoid of the introduced biological control insects Bangasternus orientalis (Capriomont) (Coleoptera: Curculionidae) and Urophora affinis Frauenfeld (Diptera: Tephritidae). Pan-Pacific Entomologist 66:162-166.

Van Soest, P. J., J. B. Roberston, and B.A. Lewis. 1991. Methods for dietary fiber, neutral detergent fiber and non-starch polysaccharides in relation to animal nutrition. Journal of Dairy Science 74:3583-3597.

Varley, G. C. 1937. The life history of some trypetid flies with descriptions of the early stages (Diptera). Proceedings of the Royal Entomological Society of London A12:109-122.

Waring, G. L. 1986. Galls in harsh environments. Proceedings of the Entomological Society of Washington 88:376-380.

Waring, G .L., and N. S. Cobb. 1992. The impact of plant stress on herbivore population dynamics. pp. 167-226 in Bernays, E. (Ed.), Insect-Plant Interactions, Vol. IV. CRC Press, Boca Raton, FL.

Watson, A. K. 1980. The biology of Canadian Weeds. 43. Acroptilon (Centuarea) repens (L.) DC. Canadian Journal of Plant Science 60:993-1004.

Watson, A. K. 1986a. Host range of, and plant reaction to, Subanguina picridis. Journal of Nematology 18:112-120.

Page 37 of 40 
Watson, A. K. 1986b. Biology of Subanguina picridis, a potential biological control agent of Russian knapweed. Journal of Nematology 18:149-154.

Watson, A. K. 1986c. Morphological and biological parameters of the knapweed nematode, Subanguina picridis. Journal of Nematology 18:154-158.

Watson, A. K., and P. Harris. 1984. Acroptilon repens (L.) DC. Russian knapweed (Compositae). pp. 105-110 in Kelleher, J. S., and M. A. Hulme (Eds.), Biological Control Programmes Against Insects and Weeds in Canada 1969-1980. Commonwealth Agricultural Bureaux, Farnham Royal, UK.

Watson, A. K., and A. J. Renney. 1974. The biology of Canadian weeds. 6. Centaurea diffusa and C. maculosa. Canadian Journal of Plant Science 54:687-701.

Wehling, W. F., and G. L. Piper. 1988. Efficacy diminution of the rush skeletonweed gall midge, Cystiphora schmidti (Diptera: Cecidomyiidae), by an indigenous parasitoid. Pan-Pacific Entomologist 64:83-85.

White, I. M., and V. A. Korneyev. 1989. A revision of the western Palaearctic species of Urophora Robineae-Desvoidy (Diptera: Tephritidae). Systematic Entomology 14:327-374.

Wilson, J. W. and P. M. W. Wilson. 1991. Effects of auxin concentration on the dimensions and patterns of tracheary elements differentiating in pith explants. Annals of Botany 68:463-467.

Woodburn, T. L. 1993. Host specificity testing, release and establishment of Urophora solstitialis (L.) (Diptera: Tephritidae), a potential biological control agent for Carduus nutans L., in Australia. Biocontrol Science and Technology 3:419-426.

Ziegler, H. 1986. Control of photosynthesis by variation of diffusion resistance in mistletoes and their hosts. Advances In Agricultural Biotechnology 19:171-185.

Zwölfer, H. 1970. Investigations on the Host-specificity of Urophora affinis Frfld. (Diptera., Trypetidae). XXV. Commonwealth Institute of Biological Control, Delémont, Switzerland. 28 pp.

Zwölfer, H. 1976. Investigations on Sphenoptera (Chilstetha) jugoslavica Obenb. (Col. Buprestidae), a possible biocontrol agent of the weed Centaurea diffusa Lam. (Compositae) in Canada. Zeitschrift für Angewandte Entomologie 80:170-190.

Zwölfer, H. 1979. Strategies and counterstrategies in insect population systems competing for space and food in flower heads and plant galls. Fortschritte der Zoologie 25:331-353.

Zwölfer, H. 1985. Insects and thistle heads: Resource utilization and guild structure. pp. 407-416 in Delfosse, E. S. (Ed.), Proceedings of the VI International Symposium on Biological Control of Weeds. Agriculture Canada, Vancouver, BC.

Zwölfer, H. and J. Arnold-Rinehart. 1993. The evolution of interactions and diversity in plant-insect systems: The Urophora-Eurytoma food web in galls of Palaearctic Cardueae. In Schultze, E.D., and H.A. Mooney (Eds.), Biodiversity and Ecosystems Function. Ecological Studies 99:211-233.

Zwölfer, H., W. Englert, and W. Pattulo. 1970. Investigations on the Biology, Population Ecology and the Distribution of Urophora cardui. Weed Projects for Canada, Progress Report 27: 17 pp. Commonwealth Institute of Biological Control.

Zwölfer, H., and P. Harris. 1984. Biology and host specificity of Rhinocyllus conicus (Froel.) (Col., Curculionidae), a successful agent for biocontrol of the thistle (Carduus nutans). Zeitschrift für Angewandte Entomologie 97:36-62.

Zwölfer, H., and M. Preiss. 1983. Host selection and oviposition behaviour in west-European ecotypes of Rhinocyllus conicus Froel. (Col., Curculionidae). Zeitschrift für Angewandte Entomologie 95:113-122. 


\section{Appendix I}

\section{Experiment 1. Size of stomatal aperture on Urophora cardui galls and ungalled Cirsium arvense stems}

Methods. Mature galls of $U$. cardui were collected from three locations in the Qu'Appelle Valley, SK. Comparisons of stomata on the gall and stems were made by painting the surface with nail varnish which was peeled when dry and placed on a microscope slide. The width and length of the aperture (inside the guard cells) of three stomata was averaged from each peel for four galls and three stems from each site.

Results. The results (Fig. 12) show that width of stomatal apertures increased with the circumference of the gall at the measurement site. Indeed, the gall circumference accounted for $80 \%$ of the variation in stomatal width. The length of the stomatal opening also increased with the gall circumference $\left(Y=0.09 x+0.34, R^{2}=0.76\right)$ but the slope was not as steep as for the width. Thus both the width and the length of the stomatal apertures increase with the diameter of the gall at the stomatal] location.

\section{Experiment 2. Transpiration losses from Urophora cardui galls and an equal length of stem from below the gall}

Methods. A galled stem, an equal length of ungalled stem from below the gall (approximately $10 \mathrm{~cm}$ ), and an ungalled stem of similar diameter were cut under water and all the leaves removed. The lower end was then sealed in a vial of water with plasticine. After 30 hours in a growth cabinet at about $23^{\circ} \mathrm{C}$, the vials were reweighed to determine transpiration losses. The test was replicated seven times. The dry weight of each gall tested was determined as a measure of its size.

Results. The transpiration losses from the ungalled stems and the stems from below the gall were similar, so they were combined for comparison with the losses from the galls. The average transpiration losses from the vials with galls was $2.72 \pm 0.29$ (SE) $g$ compared with $1.86 \pm 0.21(\mathrm{SE}) \mathrm{g}$ for the stems, $p>0.03$ for a $47 \%$ larger loss from the galls. The gall losses were not correlated with gall weight.

\section{Experiment 3. The effect of blocking stomata on Urophora cardui galls}

Methods. Galls of $U$. cardui on plants of $C$. arvense grown in pots in a greenhouse were coated with lanolin shortly after initiation $(n=58)$ and their growth compared with that of untreated galls $(n=57)$ by measuring daily the diameter and length of each gall. Daily gall volume was calculated from the daily measurements on the assumption that the galls were cylinders. The mature galls were harvested after 2 months. The number and weight of larvae in each gall were recorded and whether the plants had less than eight leaves. This resulted in four approximately equal groups.

Results. The growth of the lanolin-treated galls, whether the plant had few or many leaves, was not significantly different from the untreated galls with few leaves, so they are combined for Figure 13. Growth was slow in the first 5 days, rapid to about 14 days, and then slow to about 20 days when the galls attained maximum size. The untreated 
galls with many leaves followed the same schedule, but growth was significantly less $(p<0.001)$, following Mead and Curnow (1983).

Larvae from the treated galls were significantly heavier $11.37 \pm 0.33$ (SE) mg vs. 9.9 \pm 0.37 (SE) $\mathrm{mg}$ ( $p<0.005$ ), but the numbers of larvae per gall (5.00 vs. 4.16$)$ were not significantly different.

\section{Experiment 4. Effect of defoliation at gall initiation on Urophora cardui}

Methods. Adults of $U$. cardui were released on a caged thistle stand. When gall development was first observed, 26 thistles were paired for height and stem diameter. One plant of each pair was then defoliated. Approximately 2 months later, the galls containing mature larvae were harvested, dissected, the larvae counted and weighed after they had pupated, and the gall material dried and weighed.

Results. The number of larvae maturing per gall and the total pupal weight from the defoliated stems were significantly greater than from the undefoliated stems (Table 6). The average weight of the gall shell was not significantly different, so defoliation had increased larval survival and nutrition, apparently by reducing transpiration loss from the plant.

\section{Experiment 5. The lignin content of mature of galls of Urophora cardui galls}

Methods. The lignin content of mature galls was determined by extraction with neutral detergent (Van Soest et al. 1991) to isolate cell walls. These were subsequently subjected to a two-stage acid hydrolysis (Kaar et al. 1991) to determine acid-insoluble (klason) lignin. Acid-soluble lignin in the filtrate was quantified by spectroscopy (TAPPI 1989).

Results. The cell wall content of acid-insoluble lignin was $9.0 \%$ and acid-soluble lignin, $4.1 \%$. The $31 \%$ content of acid-soluble lignin indicates that double bonding was incomplete.

\section{Experiment 6. Potassium and nitrogen content of Subanguina picridis galls.}

Methods. Bud galls with their nematodes, gall stem cores, stem sections from above and below galls, and ungalled stems were collected in 1987 from Leader, SK, in late June, and from Regina, SK, in early and late August. Galls were also sampled from Regina in early July 1992. The galls were dried, and ground for $\mathrm{N}$ and $\mathrm{K}$ determination by autoanalysis.

Results. The levels of $\mathrm{K}$ and $\mathrm{N}$ were higher in the June galls than the stems (Table 5), but by July levels of $\mathrm{K}$ and $\mathrm{N}$ were not statistically different in galled and ungalled stems, but were significantly lower than those in galls (Table 6). By early August, $\mathrm{N}$ levels were similar and the difference in $\mathrm{K}$ was reduced (Table 5). By late August, $\mathrm{K}$ and $\mathrm{N}$ levels (not shown) in galls and stems were similar. 